Mark Dickens, Natalia Smelova

\title{
A Rediscovered Syriac Amulet from Turfan in the Collection of the Hermitage Museum ${ }^{1}$
}

DOI 10.17816/wmo65952

Abstract: Item ВДсэ-524 in the State Hermitage Museum in St. Petersburg is an amulet scroll written in Syriac which was discovered by the Second German Turfan Expedition (1904-1905) and kept afterwards in the Museum of Ethnology (Museum für Völkerkunde) in Berlin. The artifact originates in the Turkic-speaking Christian milieu of the Turfan Oasis, probably from the Mongol period. The text, however, reflects a long tradition of magical literature that goes back to ancient Mesopotamia and can be categorised as a piece of apotropaic (protective) magic. The article contains an edition of the Syriac text with translation and a discussion of its place of discovery, its overall composition and specific words and expressions found in the text. The authors point out likely connections between the Hermitage amulet and the Turfan fragments SyrHT 274-276 kept in the Staatsbibliothek zu Berlin - Preußischer Kulturbesitz and briefly discuss its similarity with amulet H彩101 discovered in Qara Qoto by the 1983-1984 expedition of the Institute of Cultural Relics, Inner Mongolia Academy of Social Sciences.

Key words: Chinese Turkestan, German Turfan Expeditions, The State Hermitage Museum, Syriac, scroll, amulet, protective magic, folk religion, Old Uyghur, Church of the East

(C) Mark Dickens, PhD (Asian and Middle Eastern Studies), Visiting Researcher, Centre for East Asian Studies, University of Groningen (dickens@ualberta.ca)

(C) Natalia Smelova, PhD (History), Research Fellow, Faculty of Theology, University of Oslo; (natalia.smelova@teologi.uio.no)

With contributions by Gideon Bohak, PhD, Professor, Department of Jewish Philosophy and Talmud, Tel Aviv University.

${ }^{1}$ We would like to express our gratitude and appreciation for all the help and support that we received from our colleagues while working on this article. First and foremost, we acknowledge the kind assistance of Nikolai Pchelin, curator of the Turfan Collection at the Hermitage. We are thankful also to Kees den Biesen, Aphrem Dawood, Jonathan Loopstra, Sergei Minov, Adrian Pirtea, Dmitrii Rukhliadev, William I. Sellers, Anna Turanskaia, Peter Zieme and His Holiness Mar Awa III, Catholicos-Patriarch of the Assyrian Church of the East.

The image of ВДсэ-524 was provided by the State Hermitage Museum, St. Petersburg (photographer D.A. Bobrova) and is published with its kind permission.

The authors are also grateful to the Staatsbibliothek zu Berlin - Preußischer Kulturbesitz and the Berlin-Brandenburgische Akademie der Wissenschaften for access to and permission to reproduce images of SyrHT 274-276, which are part of the Depositum der BERLINBRANDENBURGISCHEN AKADEMIE DER WISSENSCHAFTEN in der STAATSBIBLIOTHEK ZU BERLIN — Preußischer Kulturbesitz Orientabteilung. 


\section{Introduction}

Following in the footsteps of our colleagues Nikolai Pchelin and SimoneChristiane Raschmann, ${ }^{2}$ Ayşe Kılıç Cengiz and Anna Turanskaia, ${ }^{3}$ we continue the series of publications dealing with materials from Chinese Turkestan discovered by the German Turfan Expeditions and now kept in the State Hermitage Museum. Here we publish for the first time the text (along with translation and commentary) of the only Syriac manuscript in the cohort, a unique amulet scroll which bears the Hermitage Turfan Collection shelfmark ВДсэ-524, as well as the original German expedition find number D (II) 134. This latter is particularly informative, as demonstrated below. We start with a discussion of the modern history of the manuscript, gathered from the scroll itself, as well as external accounts. We then pass on to the formal description of the amulet, the publication of its text and accompanying translation, followed by textual and stylistic analysis of the artefact, and a discussion of particular features in this remarkable source.

The most recent history related to the rediscovery of Turfan materials in St. Petersburg - as well as the subsequent partnership between the State Hermitage Museum, the Berlin-Brandenburg Academy of Sciences (BBAW) and the Prussian Cultural Heritage Foundation (Preußischer Kulturbesitz) is described in detail in the aforementioned article by Pchelin and Raschmann. ${ }^{4}$ From this most valuable overview of written materials now stored in the Hermitage, we learn that 23 manuscripts and block prints (along with numerous art objects), were kept and exhibited in the Museum of Ethnology (Museum für Völkerkunde, later the Museum für Indische Kunst, now the Museum für Asiatische Kunst), from the time of their arrival in Berlin until the end of the Second World War. While the majority of manuscripts found by the German Turfan Expeditions were transferred to the Prussian Academy of Sciences for research purposes in 1926, the objects in question were left on display in the Museum. ${ }^{5}$

These objects still preserve the Museum's original wooden frames, some of them with markings indicating room (Raum) and exhibition bay (Koje). ${ }^{6}$

\footnotetext{
${ }^{2}$ PCHELIn \& Raschmann 2016.

${ }^{3}$ Kiliç Cengiz \& Turanskaia 2019.

${ }^{4}$ PCHELIN \& RASCHMANN 2016: 3-5.

${ }^{5}$ Ibid.: 5 .

${ }^{6}$ Kiliç Cengiz \& Turanskaia 2019: 7, esp. note 5.
} 
Based on Albert von Le Coq's original photographs, we can assume that the manuscripts were fixed on the walls alongside the murals brought back from Turfan. ${ }^{7}$ Regarding their whereabouts towards the end of the war, we rely on the account of British journalist, author and historian Peter Hopkirk, in his book Foreign Devils on the Silk Road. As the bombing raids on Berlin intensified, all movable objects, including manuscripts, sculptures and murals, were packed in crates and stored in bunkers, one of them located in the Berlin Zoo. The museum itself was bombed continuously between 1943 and 1945 by the Allied forces, resulting in the destruction of the monumental painting affixed to the Museum walls. After Soviet troops captured Berlin in 1945 , they gained access to the bunker and partially removed its contents. ${ }^{8}$ At a later stage, these valuable historical objects were deposited in the Hermitage, alongside those discovered in the Turfan area by the Russian expeditions under Dmitrii Klementz and Sergei Oldenburg. ${ }^{9}$

As we go further back in time, the history of the scroll is clearly traceable from its original German expedition find number. This appears twice on the scroll, written vertically next to line 16 as D 134 and again next to line 66 as D II 134. The three components of the number are as follows (in reverse order). The number 134 indicates the packet in which the item was stored while en route back to Berlin from Turfan; the Roman numeral II stands for the Second Turfan Expedition (November 1904-August 1905), led by Albert von Le Coq; and the letter D stands for the find-spot, Dakianus-shahri ${ }^{10}$ (the city of Dakianus). According to both von Le Coq (leader of the Second and Fourth Expeditions) and Albert Grünwedel (leader of the First and Third Expeditions), the name was used by locals to designate the ruins of the old city of Gaochang (高昌), also known as Qocho, Qara-khoja and Idiqut-shahri. ${ }^{11}$

\footnotetext{
${ }^{7}$ LE COQ 1926: plate 22.

${ }^{8}$ HOPKIRK 2006 (1st ed. 1980): 229-231.

${ }^{9}$ Peshchery tyciachi Budd 2008: 207-240, 426-455. Some objects in the Hermitage Turfan collections come also from Nikolai Krotkov, a Russian consul in Ürümqi.

${ }^{10}$ Hereafter, we reproduce this place-name as it was spelled by Grünwedel and von Le Coq.

${ }^{11}$ GRÜNWEDEL 1906: 4-7, 107, 172; LE COQ 1926: 56. Grünwedel also points out that the Turks traditionally apply this name to old ruined cities (Ibid.: 5). We can find a parallel in Uzbek (a Qarluq language and a relative of Modern Uyghur) where derivatives of the name Дақёнус have the meaning of something particularly old, archaic or antediluvian (BOROVKOV 1959: 123); we owe this information to Dmitrii Rukhliadev of the Moscow Institute of Linguistics, RAS.
} 
We do not know why von Le Coq and Grünwedel chose this rather peculiar name of the former Uyghur capital to designate their finds. We can only conjecture that this appellation was the most popular in use among the local Muslim population, due to the long-time fascination with the legend behind it.

Dakianus (Uyghur däqyanus) is a form of the name Decius, a Roman emperor (249-251) and persecutor of Christians. His name often appears in Christian hagiography and martyrdoms, most prominently in the legend of the Sleepers of Ephesus. The legend tells the story of seven (or eight) young Christian men who refused to sacrifice according to the emperor's edict and instead found refuge from persecution in a cave just outside the city of Ephesus. They all fell fast asleep in the cave, which was subsequently sealed up, waking up some 300 years later, during the reign of Theodosius II (408450). The legend was very popular in the broader Christian community and was transmitted from the 5th c. onwards in a variety of languages, with the earliest attested evidence being in Syriac. ${ }^{12}$ Interestingly, the legend was subsequently translated from Syriac into Sogdian and found among the Christian manuscript fragments brought back from Turfan to Berlin. ${ }^{13}$

The legend was also incorporated into the preaching of Islam at an early stage; it can be found in the Qur'an, in Sūrah 18 "The Cave" (الكهف), verses 9-26. Subsequently, the legend enjoyed great popularity in the Muslim world, resulting (quite apart from the abundant literary tradition in Arabic and other languages) in a symbolic translation of the sacred space of the cave to various regions where Muslims ruled. To mention just a few, there are Caves of the Sleepers (or "Companions of the Cave": Arabic أصحاب الكهف, Persian Ashāb-e Kahf, Turkish Yedi Uyuyanlar) near Amman, Jordan; Maymana in north-western Afghanistan; Afşin and Tarsus in Turkey, and Chenini in Tunisia. ${ }^{14}$ What is particularly interesting in connection with most of these locations is that, when there are ruins of a city or a village nearby, these are known among the locals as the city of Decius or, in some cases, Ephesus. ${ }^{15}$

${ }^{12}$ The earliest known text of the legend is preserved in the 5th c. Syriac manuscript of the Russian National Library, Syr. New Series 4. For the edition and translation of the text, see TONDELLO 2018 and the bibliography in this article; see also VAN EsBroecK 1994; PAIKOVA 1990.

${ }^{13}$ Sims-WiLliams 1985: 154-157.

${ }^{14}$ See, for example, BALl 2000: 134; PAIKOVA 1983.

${ }^{15}$ BALL 2000: 134. 
The location which interests us most here is the shrine of the Companions of the Cave in the Valley of Toyuq, some $60 \mathrm{~km}$ east of Turfan and $20 \mathrm{~km}$ from Qocho. ${ }^{16}$ Von Le Coq mentions it in connection with the name Dakianus-shahri (or Apsūs for Ephesus) and emphasizes it as a place of special veneration and pilgrimage for Muslims. ${ }^{17}$ Grünwedel adds an interesting detail; a stone at the entrance of the cave symbolises the dog who accompanied the young men, a Qur'anic motif added to the Christian legend. ${ }^{18}$

As a result of the archaeological investigation of Dakianus-shahri by the German Turfan Expeditions, a considerable number of manuscript fragments were unearthed in the city ruins. Although most are Middle Iranian texts in Manichaean and Sogdian scripts and Old Turkic in Uyghur script, there are also Chinese and Indian texts in Brahmi script. ${ }^{19}$ The majority of Christian finds from Dakianus-shahri were made by von Le Coq in the course of the Second Expedition. These include six Syriac fragments (T II D = SyrHT 273, T II D $319=$ SyrHT 274-276, T II D $114=$ SyrHT 277, T II D20i 5+6 $=$ SyrHT 386 $)^{20}$ and three bilingual Syriac-Sogdian fragments $($ T III D $61=$ n190, T II D $14=$ n214, T II D $67=$ n223 \& n224). ${ }^{21}$ Although von Le Coq mentions in his account the discovery of Christian fragments in the same location as Buddhist, Manichaean and Zoroastrian ones, resulting in his assumption that the same religious buildings could have been used by believers of different faiths, he does not specify the exact find spots. Neither are the archaeological layers indicated, so there is no external clue for dating any of these fragments. We can guess that perhaps some of the Christian fragments were found within a small structure outside Qocho city walls on the east bank of the river, considered to be a Christian church building due to

\footnotetext{
${ }^{16}$ For local legends connected with the shrine in Toyuq and the city of Dakianus, see KATANOV 1894; YAKUP 2005: 264-271.

${ }^{17}$ LE COQ 1926: 56, 93-94; see also PARRY 2012: 167-168.

${ }^{18}$ GRÜNWEDEL 1920: 167. He, however, was convinced that the shrine was of Manichaean rather than Muslim origin.

${ }^{19}$ SUNDERMANN 2004.

${ }^{20}$ SyrHT 273 is a small fragment of a calendrical table (see DickENS \& Sims-Williams 2012: 282); SyrHT 274-276 are addressed below, as these fragments are relevant to the Hermitage scroll; SyrHT 277 is a fragment from a lectionary containing the Gospel reading for the First Sunday of the Annunciation/Advent (see DickENS 2016: 32-33); and SyrHT 386 is a folio containing Psalm 148:1-3, with the verses written in reverse order (see DiCKENS 2016: 29-30). For the overall survey and description of the Syriac manuscripts from Turfan, see HUNTER \& DiCKENS 2014.

${ }^{21}$ Sims-Williams 2012: 24-26.
} 
the discovery of the famous mural with unusual iconography interpreted by von Le Coq as a fragment of the Palm Sunday scene. ${ }^{22}$

The best-known Christian site on the Silk Road consists of the ruins of a monastery near Bulayiqq, to the north of Turfan, excavated for the first time by Theodor Bartus during the Second German Expedition. However, traces of a Christian presence are attested in various other locations in the Turfan area, including Qocho, Toyuq, Sängim and Kurutka. Taking into account all the above evidence, we cannot rule out the possibility that a Christian community existed in the important caravan city of Qocho. In addition to Christian texts from Qocho written solely in Syriac and a few examples of bilingual Syriac-Sogdian texts, there are also examples of Syriac interacting with the predominantly Turkic milieu of the city. One such witness will be examined in the present article, a discovery made all the more interesting by the fact that it provides further evidence of the use of Syriac not only in an ecclesiastical or liturgical context, but also in the realm of magic and folk practices.

These are just some snapshots of the historico-cultural context from which the Syriac amulet scroll emerged. We turn now to the description of the manuscript.

The scroll ВДсэ-524 measures $89.5 \mathrm{~cm}$ long by $7.0 \mathrm{~cm}$ wide ${ }^{23}$ and is written on one side of thin cotton paper. Originally, the scroll was folded several times, probably in a style resembling Chinese harmonica books. The traces of folding can be observed, at roughly equal intervals, between lines 8 and 9 , 19 and 20, 29 and 30, across line 39, between lines 48 and 49, 57 and 58, 67 and 68. The paper is slightly damaged on the edges where it was folded. The upper part of the scroll also shows some damage from insects. In the course of restoration, the original scroll was glued on white opaque paper. For the purpose of display, it was further glued onto two overlapping sheets of modern paper, dark beige in colour.

The amulet is lacking its initial and final parts and contains 78 lines, the first of which preserves only one recognizable letter. The text is written in black ink with occasional use of red ink. There is a word in red ink that is

${ }^{22}$ LE COQ 1926: 77-78, plate 9. On this mural, thought to have been created during the T'ang period, a priest holding a vessel and a censer with incense stands in front of a group of three people with branches of green leaves in their hands. See also PARRY 2012: 170.

${ }^{23}$ These measurements are taken from PCHELIN \& RASCHMANN 2016: 14. It is not possible at present to provide more precise measurements, including line length and spacing. 
repeated continuously throughout the text, on 11. 17, 19, 23, 31, 48, 62 and 78 (on the nature and function of this word, see below). Moreover, there are punctuation signs in red ink on 11. 24, 70, 72, 74, 75, 76 and 78. The text is written in an irregular script of East Syriac origin with elements of monumental and cursive writing; it shares common features with some Syriac and Old Turkic texts in Syriac script found in Qara Qoto (also referred to as Khara Khoto or Khara-khoto in the literature), an abandoned city located in Inner Mongolia. $^{24}$

We have been able to identify three or possibly four different scribal hands. There seems to be a slight palaeographic change between lines 4 and 5 , although this might be the result of the scribe changing pens. A more distinct change which looks like a new scribal hand is apparent on lines 57 and 58 (although it is difficult to spot exactly where the change occurs, the hand on line 56 seems quite different from that on line 59). Finally, another change in hands is evident between lines 68 and 69.

A distinctive feature which is observed throughout the manuscript is the use of ligatures, such as rd (11. 16, 21, 23, 27, 34, 44, 46(?), 52, 53, 54, 73), $\checkmark$ (1. 48; this seems to be accidental due to the shortage of space at the end

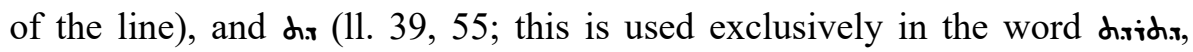
"which expelled" and is a ligature less commonly seen in Syriac manuscripts). The use of diacritics throughout the text is irregular. In some cases, seyame (a plural indicator) may be used as an indication of vocalization, e.g. in the demonstrative pronoun $\leqslant$ ros (1. 31)/ $<$ הon (1. 62, placed above the letter instead of below it). In some other instances, however, we cannot explain their use. ${ }^{25}$

The authors are deeply indebted to Professor Gideon Bohak of Tel Aviv University for his assistance in deciphering the text, improving our initial readings, outlining the structure of the text, tracing the parallels in Jewish magical texts and discerning the role of several important words used in this amulet, notably the recurrent rubric.

\footnotetext{
${ }^{24}$ Yoshida \& CHIMEDDORJI 2008: 9, 407-409.

${ }^{25}$ For more on what seems to be the same phenomenon, see DiCKENS 2013: 12.
} 


\section{Syriac text $\mathrm{t}^{26}$}

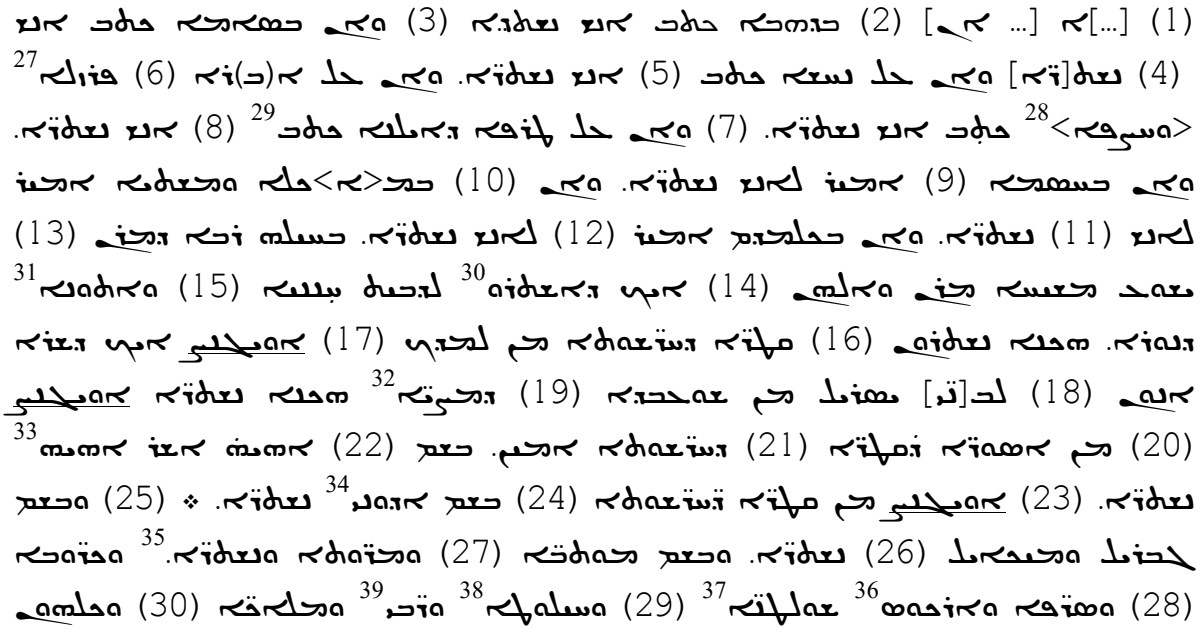

${ }^{26}$ The diplomatic transcription of the text provided here reproduces the original orthography, diacritics and punctuation. Corrected readings are in footnotes, with lost or unreadable letters filled in, wherever possible, within the text. Sigla used in this edition are as follows:

$[\ldots]$ text lost due to paper damage (number of letters unknown);

$[\ll]$ reconstruction of lost text;

$(\approx)$ reconstruction of unreadable (effaced) letters;

$<\ll>$ letters or words added above lines;

$<$ rubric.

${ }^{27}$ Read $\sim_{1 \text { iqna }}$

${ }^{28}$ The first half of this line is difficult to read, due to lacunae and a word to be inserted that is written above the line.

${ }^{29}$ There appears to be an upright letter at the end of this line (perhaps $<$, the first letter on the next line), but the lacunae that follow sh (the final complete word that is visible) make it impossible to discern more.

${ }^{30}$ Read oidrxx, "were released".

${ }^{31}$ Read rudir $\rightarrow$, "from the furnace".

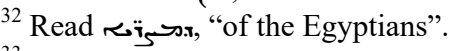

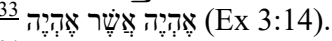

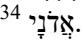

${ }^{35}$ Read ridur, "may he be loosened".

${ }^{36}$ Read סم

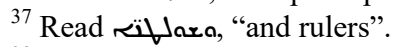

${ }^{38}$ Read waldowers".

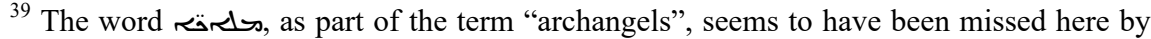
the scribe. 


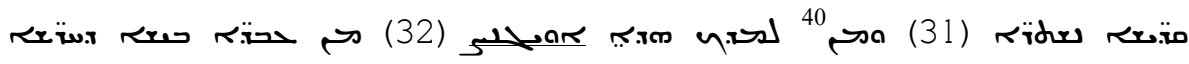

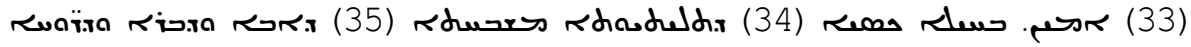

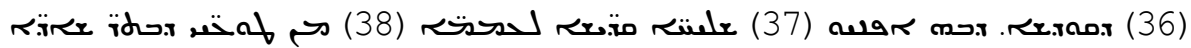

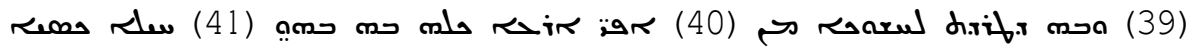

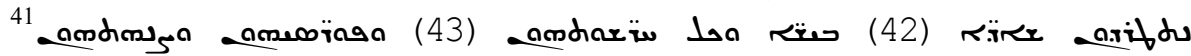

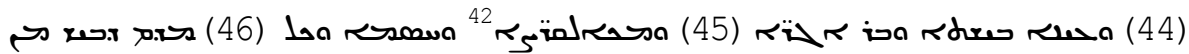

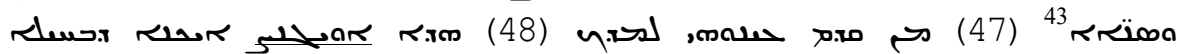

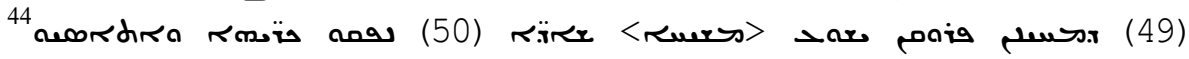

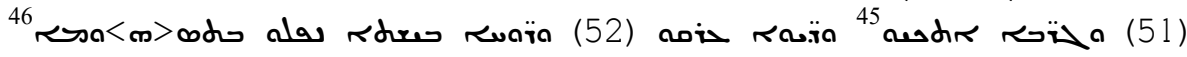

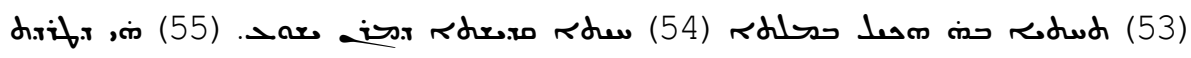
للve

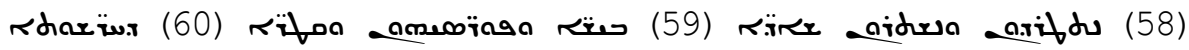

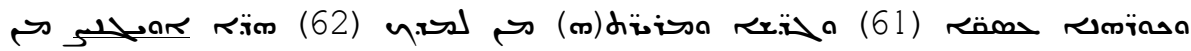

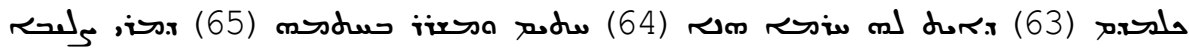

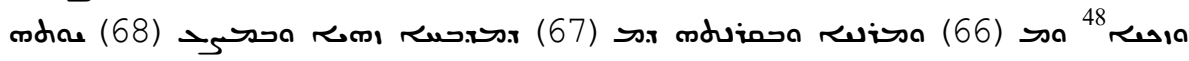

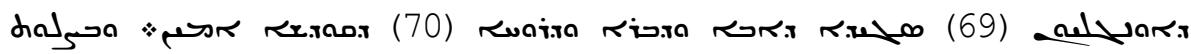

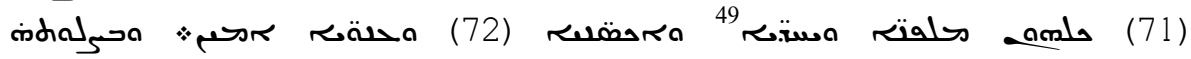

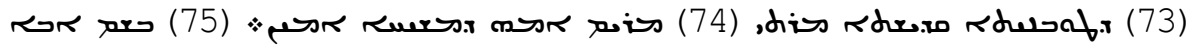

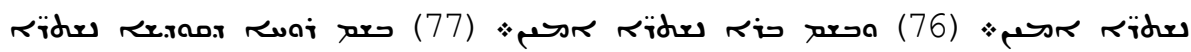

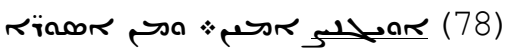

${ }^{40}$ Misplaced ה̧a, "and from".

${ }^{41}$ Read amd us, "their contrivances".

${ }^{42}$ Read $r_{5}$ inloraso, "and slanderers".

${ }^{43}$ Read 2 , "from enemies".

44 The $a$ at the beginning of this verb seems misplaced; in all other instances in this series

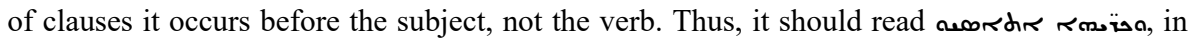
parallel with e.g. .

${ }^{45}$ Read sexidr, "were cleansed". This may be an indication of /d/ assimilating to /t/, assuming that this text would be spoken aloud by a Uyghur native speaker in the actual ritual it was meant to be used with. Uyghur does not have the sound $/ \theta /$, so the beginning of the word

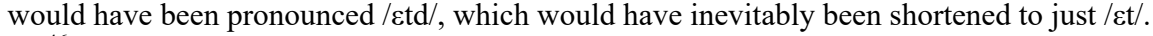

${ }^{46}$ Read samd, "in the abyss".

${ }^{47}$ Read محمتح, "tombs".

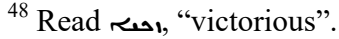

${ }^{49}$ Read سشت:ه, "and solitaries". 


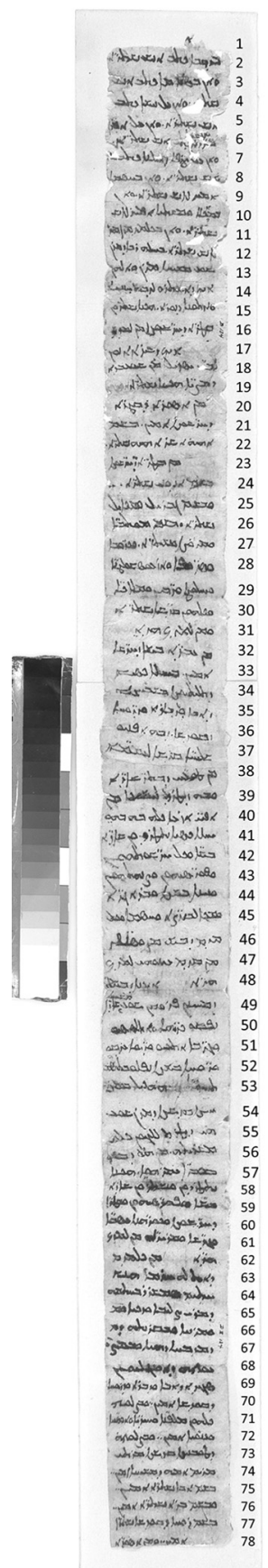

Pl. 1. ВДсэ-524 (with line numbers). (C) The State Hermitage Museum, St. Petersburg, 2017 


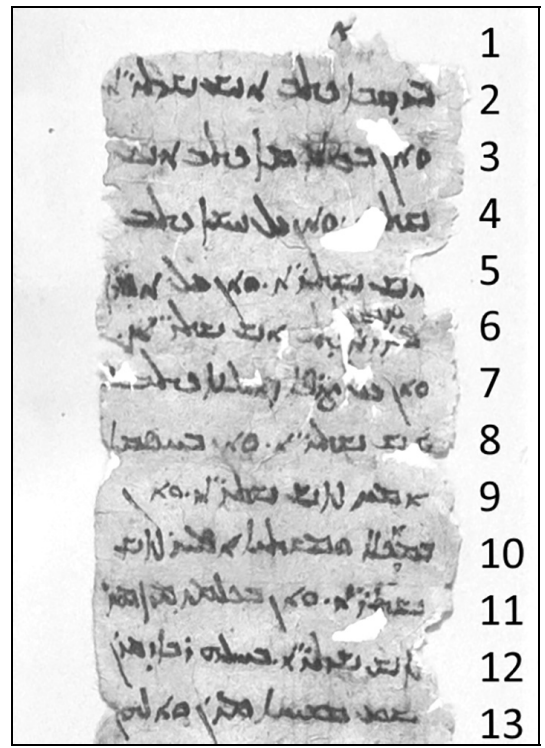

P1. 2. ВДсэ-524. Lines 1-13.

(C) The State Hermitage Museum, St. Petersburg, 2017

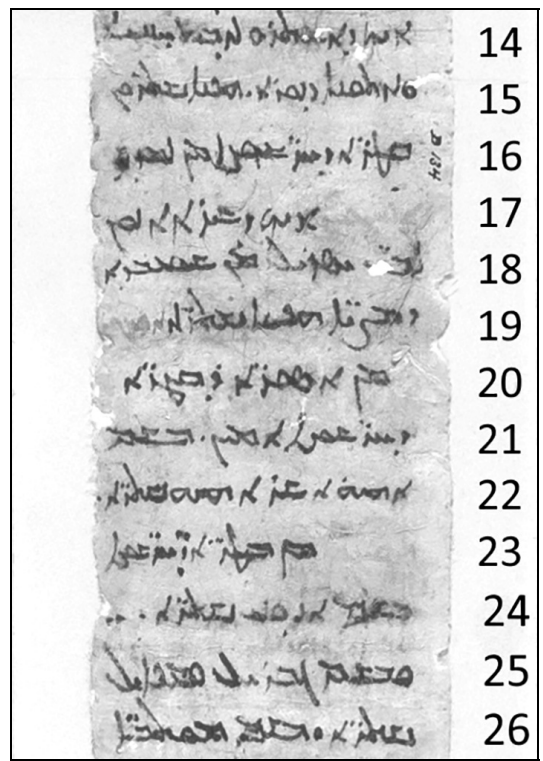

P1. 3. ВДсэ-524. Lines 14-26.

(C) The State Hermitage Museum, St. Petersburg, 2017 


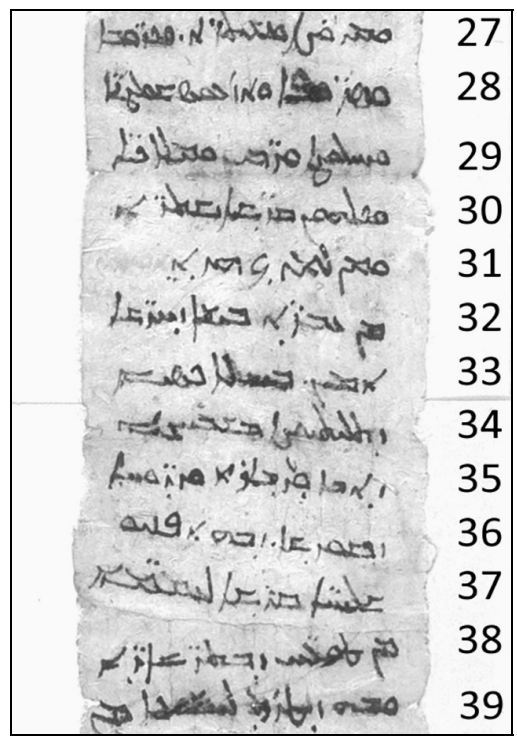

P1. 4. ВДсэ-524. Lines 27-39.

(C) The State Hermitage Museum, St. Petersburg, 2017

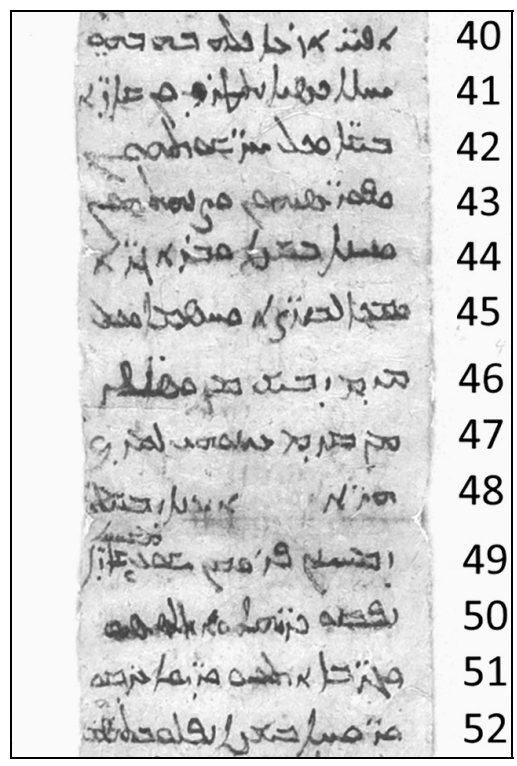

P1. 5. ВДсэ-524. Lines 40-52.

(C) The State Hermitage Museum, St. Petersburg, 2017 


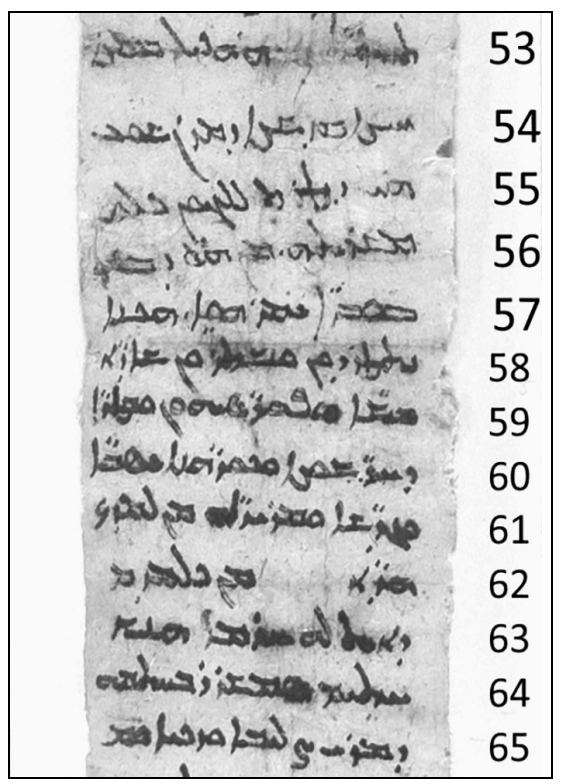

P1. 6. ВДсэ-524. Lines 53-65.

(C) The State Hermitage Museum, St. Petersburg, 2017

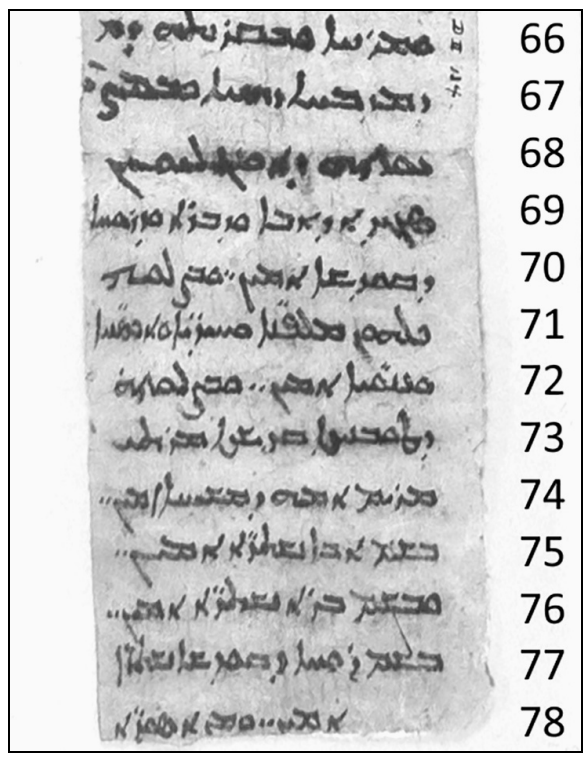

P1. 7. ВДсэ-524. Lines 66-78.

(C) The State Hermitage Museum, St. Petersburg, 2017 


\section{Translation $^{50}$}

(1) [...] [if] (2) a person has written (a spell against the client) on gold, may he (the client) be loosened, (3) and if a person has written on silver, (4) may he (the client) be loosened, and if a person has written on bronze, (5) may he (the client) be loosened. And if a person has written on lead, (6) iron or an earthen vessel, ${ }^{51}$ may he (the client) be loosened. (7) And if a person has written on the leaf of a tree, (8) may he (the client) be loosened. And if (a spell has been) spoken in jealousy (9) by a person, may he (the client) be loosened. And if (10) spoken on food and drink by a person, (11) may he (the client) be loosened. And if spoken on anything (12) by a person, may he (the client) be loosened.

By the great power of our Lord (13) Jesus Christ, our Lord and our God, (14) just as the companions of Hananiah were released (15) from the fiery furnace, so may (16) the bonds of sorcery be loosened from he who puts on (this amulet), (17) Ögünč. Just as He (God) set free (18) the Sons of Israel from the subjugation (19) of the Egyptians, so may Ögünč be loosened (20) from the chains of the bonds (21) of sorcery, Amen!

In the name of (22) I AM WHO I AM, may Ögünč be loosened (23) from the bonds of sorcery. (24) In the name of Adonai, may he be loosened. (25) And in the name of Gabriel and Michael, (26) may he be loosened. In the name of thrones, (27) dominions and [sic] may he be loosened. And (in the name of) cherubim, (28) seraphim, principalities, rulers, (29) powers, arch(angels), angels (30) and all of the saints, may (31) he who puts on this (amulet), Ögünč, be loosened (32) from evil deeds of enchantment, (33) Amen!

It was by the secret power (34) of the praiseworthy Trinity (35) of the Father, of the Son and of the Holy Spirit, (36) that the holy apostles turned back (37) the nations (38) from the false worship of demons ${ }^{52}$ (39) and it (the Trinity) drove out darkness from (40) the face of the whole earth. By

${ }^{50}$ Sigla used in the translation are as follows:

[text] translation of the reconstructed text;

(text) semantic additions by the translators;

text rubric

${ }^{51}$ Variant: "a potsherd".

${ }^{52}$ Lit. "false worship that is after demons", with the words for "false worship", "after" and

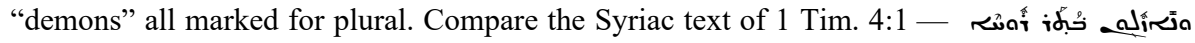

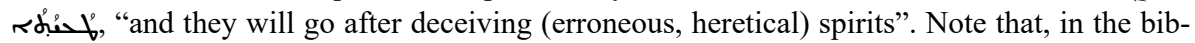
lical text, none of the words of interest are marked for plural. 
this (41) secret power may evil demons be driven away (42) and all their sorcery, (43) their stratagems and their contrivances, (44) the evil eye and demons of lunacy, (45) slanderers and jealousy and every-(46)thing that is evil from enemies (47) before the eyes of him who puts on (48) this (amulet), Ögünč.

Just as, by the power (49) of the giver of life, our Saviour Jesus Christ, demons (50) went out (i.e. were expelled), the sick were healed, (51) lepers were cleansed, devils fled, (52) evil spirits fell into the deep abyss (53), indeed by the living and holy word (54) of our Lord Jesus, (55) which (word) expelled the Legion to (56) its (proper) dwelling from that (man) who lived in (57) the tombs, so (58) may the evil demons (59) and their stratagems and the bonds (60) of sorcery and grievous illnesses, (61) accidents and (all) his sadness be driven away and loosened from him who puts on (62) this (amulet), Ögünč, from everything (63) that he has.

This anathema (64) is sealed and confirmed by the seal (65) of the victorious Cross $^{53}$ of the Lord (66) and by the horns (67) of the glorious altar and by the medi-(68)ation of the venerable Gospel (69) of the Father, of the Son and of the Holy (70) Spirit, Amen. And by the prayer (71) of all the teachers, solitaries, pilgrims (72) and ascetics, Amen. And by the prayer (73) of the Blessed Holy Lady (74) Mary, the mother of Christ, Amen.

(75) In the name of the Father, may he (the client) be loosened, Amen. (76) And in the name of the Son, may he (the client) be loosened, Amen. (77) In the name of the Holy Spirit, may Ögünč be loosened, (78) Amen.

And from chains...

\section{The overall text and its structure}

Syriac amulets (along with incantation bowls, which are very similar genre-wise to amulets) have received sporadic scholarly interest in the past, ${ }^{54}$ but that interest has increased in recent decades, thanks to the work of scholars like Tapani Harviainen, Joseph Naveh and Shaul Shaked, Philippe Gignoux, Erica C.D. Hunter, Lucas van Rompay, J.B. Segal and Ali Faraj. ${ }^{55}$

\footnotetext{
${ }^{53}$ Lit. Mar Șaliba.

${ }^{54}$ Important exceptions include HAZARD 1893; GOLLANCZ 1912 and MONTGOMERY 1918.

${ }^{55}$ HaRViainen 1978; NAVEH \& SHaKed 1985; Gignoux 1987; HunTer 1987; HunTer 1990; Van Rompay 1990; Hunter 1993; NAVeh \& SHaKed 1993; Hunter 1999; Segal 2000, 147-150; HUNTER 2009; FARAJ 2010.
} 
Several other Syriac amulets found at Turfan are extant in the Berlin Turfan collection, housed in the Staatsbibliothek zu Berlin — Preußischer Kulturbesitz, the Berlin-Brandenburgische Akademie der Wissenschaften and the Museum für Asiatische Kunst. A number of these amulets have been published by Hunter, including two fragments of a Syriac amulet (SyrHT 99 and SyrHT 330 $)^{56}$ containing portions of "The Prayer of Mar Tamsis", ${ }^{57}$ a very small personal amulet (SyrHT 152) ${ }^{58}$ with only two Syriac words and a beautifully drawn cross on it, ${ }^{59}$ two fragments from an amulet (n364 and n $365)^{60}$ containing part of the "Anathema of Mar Cyprian" from another amulet (SyrHT 102), ${ }^{62}$ also containing text from the same Anathema. ${ }^{63}$ Additionally, a Christian Sogdian amulet (n396) that mentions Mar Cyprian has been published by Nicholas Sims-Williams. ${ }^{64}$

Other Syriac scroll amulets described in the literature, albeit not from Turfan, include 1) one from Urmi, Persia (most probably from the 19th c.), published by Willis Hatfield Hazard; ${ }^{65}$ 2) one inscribed on a silver sheet and published by Joseph Naveh and Shaul Shaked (the provenance and current whereabouts of which are unknown); ${ }^{66} 3$ ) three written on animal skin, most probably from 6th or 7th c. Iran and published by Philippe Gignoux; ${ }^{67}$ and 4) two from the 19th c. Kurdistan, published by Hunter.

It needs to be remembered that the complete scroll amulet from the Hermitage is no longer extant; as noted above, the beginning and ending of the text are missing. Nonetheless, what remains of the scroll, one of the longer Christian texts found at Turfan, is fascinating and full of language and themes typically found in such amulets.

Our scroll amulet begins with a list following the general formula "if a person has written (a spell against the client) on/with , may he (the cli-

\footnotetext{
${ }^{56}$ Prayer-amulet B in HunTER \& DiCKENS 2014: 453.

${ }^{57}$ HunTER 2013.

${ }^{58}$ Prayer-amulet E in HUNTER \& DiCKENS 2014: 453.

${ }^{59}$ HunTER 2017: 82-83.

${ }^{60}$ Prayer-amulet F in HunTER \& DiCKENS 2014: 453.

${ }^{61}$ HUNTER 2017: 85-86, 88.

${ }^{62}$ Prayer-amulet C in HunTER \& DiCKENS 2014: 453.

${ }^{63}$ HunTER 2017: 86-88. See also HunTER 2018, which discusses the aforementioned amulets as well.

${ }^{64}$ Sims-WiLliams 2020.

${ }^{65}$ HAZARD 1893.

${ }^{66}$ NAVEH \& SHAKED 1985: 62-68.

${ }^{67}$ GignOUX 1987.
} 
ent) be loosened". This is followed by a list following the formula "if (a spell has been) spoken in/on __ by a person, may he (the client) be loosened".

The scroll then invokes the power of Christ, continuing to use the phrase "let him be loosened", after which it transitions to a section of Old Testament historiolae (narrative incantations). Reference is made to two examples of deliverance from the Hebrew Bible: that of the three young men from the fiery furnace (Dan. 3) and that of the Israelites from Egypt (Ex. 12-15). This is followed by an invocation involving some of the divine names in the Hebrew Bible, after which the archangels Gabriel and Michael and then the nine angelic ranks are invoked.

After this there is a turn from Old Testament to New Testament historiolae, beginning with references to the name of the Trinity, the apostles and the one "who drives out darkness from the face of the earth". These invocations lead to a list of magical practices and entities that the wearer of the amulet is to be protected from.

After a list of miraculous deeds performed by Christ, the amulet refers to his encounter with the Gadarene ${ }^{68}$ demoniac $^{69}$ recounted in Matt. 8:28-34; Mark 5:1-20; Luke 8:26-39. Once again, a list is given of demonic activity from which the amulet is to protect its wearer. The extant part of the amulet concludes with references to a seal, the altar, the Gospel, the prayers of the saints and a three-fold loosening in the name of the Trinity. ${ }^{70}$

\section{Specific terms in the text}

A number of terms in the text deserve special mention. First is the Syriac word r.shr, "let him be loosened"71 (11. 2, 5, 6, 8, 9, 11, 12, 19, 22, 24, 26, 27, 30, 75, 76 and 77), along with its variant -aider, "let them be loosened" (11. 15 and 58), from rix, "to loosen". The language of binding and loosing is very common in Christian amuletic texts and can be traced back in a Christian sense to the words of Jesus in two different contexts. Matt. 16:19

\footnotetext{
${ }^{68}$ Textual variants have "Gerasene" or "Gergesene".

${ }^{69}$ Again, textual variants mention two demoniacs.

${ }^{70}$ As noted above, this overview of the structure of the amulet is strongly informed by observations from Gideon Bohak.

${ }^{71}$ Or "dissolved, unsealed, opened".

${ }^{72}$ All biblical passages in Syriac are taken from the Peshițta text.
} 


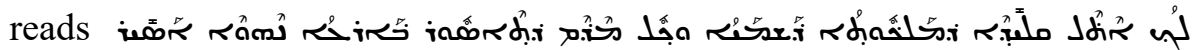

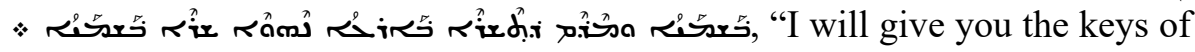
the kingdom of heaven and whatever you bind on earth will be bound in heaven and whatever you loose on earth will be loosed in heaven". In Matt.

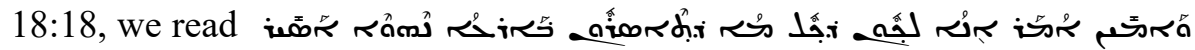

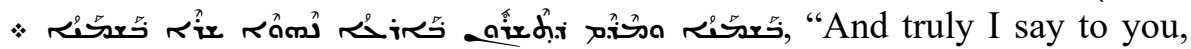
that whatever you bind on earth will be bound in heaven and whatever you loose on earth will be loosed in heaven". The practice of binding and loosing (or loosening), however, predates the time of Jesus and his use of these terms without elucidation suggests that his audience would have already been familiar with them. In addition to their use in Jewish circles, ${ }^{73}$ we encounter them (along with the related concept of "knots") in a whole host of folk and religious contexts around the world. ${ }^{74}$ Notably, as Bohak observes, "most of the magical technical terms in the Syriac text [many discussed below] are paralleled in Aramaic magical texts, including the verbs $r_{\text {ir }}$ [loosen, unfasten, untie, unbind], ri [drive away, drive out, expel], [flee], terms such as م م [knot], rdariw [magic, sorcery, witchcraft],

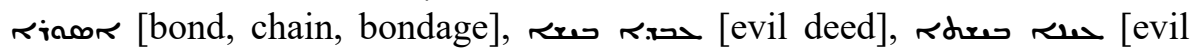

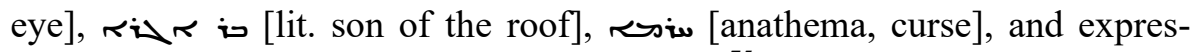
sions like irs wo [sealed and confirmed]". 75

Although Matt. 18:15-18, the original context of the second verse, is concerned with reproving those in the church who have committed sin, Christians have typically associated the language of binding and loosing with the first verse. Its context (Matt. 16:13-20) concerns Peter's declaration at

\footnotetext{
${ }^{73}$ On which, see the discussions in EMERTON 1962; DerRetT 1983; Hiers 1985.

${ }^{74}$ Piccaluga 2005, passim.

${ }^{75}$ Personal correspondence, Feb. 6, 2021. Note that the Jewish parallels mentioned throughout this article are not an indication of direct Jewish influence per se, but rather evidence of the common origins of all magical texts in Aramaic dialects (whether Jewish Aramaic, Mandaic or Christian Syriac), namely the Near East of Late Antiquity. Although there is no archaeological evidence of a Jewish community in Turfan, manuscript fragments in Hebrew script, written in either the Hebrew or (Judeo) Persian language, have been discovered at Dunhuang and Dandan-i Uiliq in Xinjiang, China (http://turfan.bbaw.de/projekt/ sprachen-und-schriften; on the latter, see UTAS 1968 [1969]), suggesting that there were likely Jewish traders who frequented the region. Although a polemical dialogue between a Christian and a Jew, written in Syriac, was discovered at Turfan (HUNTER \& DicKENS 2014: 31, 110111), such texts were standard ways of training monks and clerics in the art of convincing those from other religious backgrounds of the merits of Christian teaching and do not necessarily imply that there were Jews in Turfan to debate with.
} 
Caesarea Philippi that Jesus was the Messiah, in response to which Christ pronounced Peter to be blessed and awarded him "the keys of the kingdom of heaven" mentioned above. From this verse comes the idea that binding and loosing are ultimately connected to authority and concerned with allowing or not allowing things to take place, based on a verbal formula in which the thing to be desired is loosened or the thing to be avoided is bound. Interestingly, the extant portion of our amulet scroll does not include any references to binding, which typically employ the Syriac verb ior, "to bind, fasten, tie, take into bondage, compel".

The word nas occurs four times in the text (11. 16, 31, 47 and 61). As far as we can tell, it appears to be an acronym for the who puts on (this amulet)" ${ }^{76}$ In several places where this term occurs in the text, it is followed by the word rim, "this (f)", obviously referring to the amulet.

Another prominent word in the text is a recurring rubric (11. 17, 19, 23, 31, 48, 62 and 78). In most cases it is badly faded and barely legible, but image enhancement has confirmed what the authors suspected through visible inspection of the digital images. ${ }^{77}$ The word can be read as war, representing the transliteration into Syriac script of the Turkic word ögünč, ${ }^{78}$ a noun formed from the verbal stem ögün-, "to praise oneself, boast", ${ }^{79}$ itself derived from the stem $\ddot{o g}$-, "to praise". ${ }^{80}$ Although the standard meaning of the noun ögünč was "self-praise", ${ }^{81}$ it seems to have had an alternative meaning in Christian texts, where it was used as simply a word for "praise, glory". This can be seen most clearly in the 14th c. Codex Cumanicus, as Kaare Grønbech noted in his Komanisches Wörterbuch: "ögünč, öjgünč [137,18] Lob. ataya ögünč... bolsun dem Vater sei Lob 151,17. ögünč berlobpreisen, 'laudem dare' 141,9 ". ${ }^{82}$ The first two examples of ögünč occur in the following lines from a hymn to the Virgin Mary:

${ }^{76}$ The authors are indebted to Gideon Bohak for this suggestion, which fits the context of the places where we find this word in the amulet.

${ }^{77}$ The authors are grateful to Professor William I. Sellers of the University of Manchester for his assistance.

${ }^{78}$ The authors wish to thank Dmitrii Rukhliadev for this suggestion, which has proven to be the most likely reading.

${ }^{79}$ ClausON 1972: 110-111.

${ }^{80}$ Ibid.: 100 .

${ }^{81}$ Ibid.: 110.

${ }^{82}$ GRøNBECH 1942: 182. 
Sionda biz kim turalïm, ögünč yïrïn saa aytalïm! We will live in Zion; we will sing to you with songs of praise! $!^{83}$

Barča birgä qopsap turur, ögünč tekši berip turur. All together chanting Psalms; uniformly giving praise. ${ }^{84}$

A third instance of the word in the Codex Cumanicus is found in a prayer directed to Christ:

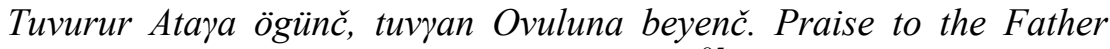
who begets; joy to the Son who was begotten. ${ }^{85}$

However, the rubric in our text represents more than just a word meaning "praise, glory". It is in fact the name of the client for whom this scroll amulet was made. ${ }^{86}$ Indeed, it may well have been a common name amongst the Uyghurs. ${ }^{87}$ It is recorded in Juwayni's History of the World Conqueror (1260) as the name of the brother of the idi-qut, the ruler of the Uyghur Kingdom of Qocho, allied with the Mongols after submitting to them in 1209. In the wake of a Uyghur plot to kill all the Muslims living in Beshbaliq (an important city in the Uyghur Kingdom), a plot that involved the idi-qut, himself, Ögünč was the one who cut off his brother's head and subsequently succeeded him as the next idi-qut (the events in question took place in $650 \mathrm{AH} / 1252-53 \mathrm{CE}){ }^{88}$

The recurring phrase " בr "in the name of" (11. 21, 24, 25, 26, 75, 76 and 77) is not surprising to find in an amulet that is concerned with battling spiritual enemies. Invoking the name (and hence the spiritual authority) of God is a concept that has deep roots in the Judeo-Christian scriptures. Thus, David meeting Goliath in battle does so "in the name of the Lord of hosts, the God of the armies of Israel" (1 Sam. 17:45) and the Davidic king celebrated in the Messianic psalms cuts off the nations "in the name of the Lord" (Ps. 118:11).

${ }^{83}$ GARKAVETS 2019: 98.

${ }^{84}$ Ibid.: 104.

${ }^{85}$ Ibid.: 122 . The authors thank Peter Zieme for his assistance with philological matters related to these quotations from the Codex Cumanicus.

${ }^{86}$ The authors once again thank Gideon Bohak for this observation.

${ }^{87}$ RÁSONYI \& BASKI 2007: 592.

${ }^{88}$ References to Ögünč in the Persian text can be found in QAZVĪNī 1912: 38-39; see BOYLE 1958: 52-53 for the English translation. 
Similarly, in the New Testament, Christ exhorts his followers to pray in his name (John 14:13-14; 15:16; 16:23-27) and the disciples, after the day of Pentecost, heal others "in the name of Jesus Christ of Nazareth" (Acts 3:6). Later on, Paul exorcises evil spirits "in the name of Jesus Christ" (Acts 16:18). Just as the aforementioned Gospel passage on binding and loosing was easily incorporated into amuletic material, so too was the notion of performing an action in the name of one with more spiritual authority than the agent. However, in the case of our amulet, performing the action in the name of angels and other supernatural beings that are considered to have more spiritual authority than the speaker (in order to make the invocation more powerful in the popular mind) testifies to folk beliefs rather than the traditions of the Judeo-Christian Scriptures.

We come now to words that are found in specific places in the text, in contrast to those above that are scattered throughout it. As Bohak notes,

The first twelve lines of the amulet (as well as previous lines, which are missing) take the format of "If a person worked witchcraft (on the client) by method X, may he (the client) be loosened", with each sentence covering a different type of aggressive magic, in the hope of covering all possibilities. This format - whose origins go back to Akkadian magical texts, such as the Maqlû-spells - is well known in Jewish magic. The clearest example is found in the Pishra de-Rabbi Hanina ben Dosa, a late-antique magical text in Aramaic which aims to dissolve ( $p \check{s} r)$ and loosen ( $\check{s} r y$, the same verb as in the Syriac amulet) every possible act of witchcraft performed against the client. ${ }^{89}$

We have translated the phrase vr sh s.... has written", with the following parenthetical phrase "a spell against the client" not included in the text, but understood from the context. In this case, $\Delta \ll$, "a person" stands for a perpetrator of magic against the client for whom the amulet was written.

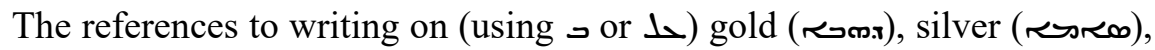

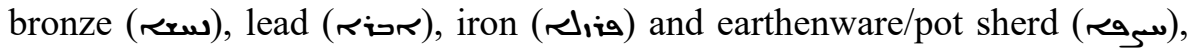

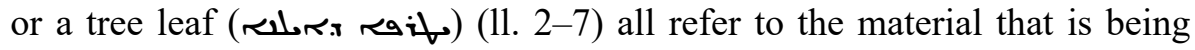

${ }^{89}$ Personal correspondence, Feb. 6, 2021. On the Pishra de-Rabbi Hanina ben Dosa, see TOCCI 1986 and BOHAK 2019. 
written upon (rather than the material that is used for the writing). ${ }^{90}$ They seem to cover a wide spectrum of materials on which magical texts could be written in antiquity. Note the following regarding things written on various metals in the ancient Mediterranean:

Among the types of metal used for incantations or amulets in Egypt, lead was reserved for binding incantations, as was customary elsewhere in the Graeco-Roman world... In Egypt, as elsewhere, bronze, silver, and gold strips of metal were used for incantations for healing, deliverance, or favour. ${ }^{91}$

Although use of the last three metals typically did not involve maleficent examples of magic that would necessitate protection of the type offered by our amulet, lead and clay are notable exceptions:

In the competitive face-to-face societies of the ancient Mediterranean it was not uncommon for people to try to handicap a competitor and gain an advantage by what are called curses or 'binding spells'... The preferred medium for these incantations was a thin sheet of lead, lead alloys, or other metals - more for practical reasons, initially, than ritual ones - though pottery sherds, limestone, gems, and papyrus were also used. The inscribed object was then deposited close to the underworld deities or untimely dead being summoned to help - in a chthonic sanctuary, a grave, or an underground body of water (a well, a fountain, baths). The object might also be buried close to the target being hindered - in the hippodrome or the stadium, for incantations against competitors; near the home or place of work of an adversary. ${ }^{92}$

Pot sherds, also known as ostraca, were cheap and readily available in the ancient Mediterranean, ensuring their use for all sorts of writing, including incantations:

\footnotetext{
${ }^{90}$ The one possible exception to this might be the reference to gold, given the practice of chrysography (writing in gold ink on blue paper), but we have no indication that this technique was used in magical texts.

${ }^{91}$ DE BRUYN 2017: 46.

${ }^{92}$ Ibid.: 121-122.
} 
They were favoured in areas where pottery was plentiful but papyrus had to be brought in, as in the Egyptian desert. Numerous texts written on ostraca have been found, for instance, among the remains of the monasteries in the region of Thebes. Many of the texts are letters or short documents, but the finds also include biblical and liturgical texts. Ostraca were not as malleable or easy to carry as papyrus, which limited their usefulness for amulets. They were more suited to binding incantations, antagonistic devices that were deposited in earth or water (a grave, the baths, the target's house or workplace) in order to take effect. $^{93}$

These observations of materials used in the Graeco-Roman world are complemented by what we know about materials used for magical texts in a Jewish context. Thus, Jewish amulets crafted between biblical times and the Byzantine period were

made of metal lamellae, that is, thin plates or pieces of foil made of gold, silver, bronze, copper or lead... A few amulets made of lead are particularly interesting as these are meant to invoke a curse on someone. While lead amulets - so-called defixiones - were very popular in Roman culture, they were rather unusual in ancient Jewish culture, it seems. ... a variety of metals are mentioned in instruction texts describing writing materials, such as gold, silver, bronze, iron, lead, tin and copper... The purpose of these so-called defixiones was an aggressive one, viz. to harm or even kill somebody. The rather rare evidence of a Jewish lead amulet has a fine counterpart in an instruction text from the Cairo Geniza: For extermination: [Take] a lamella of lead [and] write [on it] in the first hour of the day and bury it in a fresh grave. ${ }^{94}$

In addition to possible spells that were written down, our amulet also concerns itself with potential incantations that were spoken. It specifically singles out vass, "competition, envy, jealousy" (1. 8, see also 1. 45), that most basic of human passions. Indeed, these amuletic texts make frequent mention of envy, jealousy and covetousness, along with the relational difficulties that come in their wake. Thus, in a 72-page codex containing various amulets,

\footnotetext{
${ }^{93}$ Ibid.: 45.

${ }^{94}$ REBIGER 2017: 341-342, 349-350.
} 
written in 1802/03 in Turkish Kurdistan and published by Hermann Gollancz, we read the following, more extensive description of what many amulets seek to guard against: "may there too be annulled from the house of him who beareth these writs, jealousy and enmity, disputes, strifes, and divisions; by that Word which spake to the water and it became wine, may (men) be at peace with one another, may the gates of mercy and compassion be opened, and the mouth of evil men be stopped from off him". 95

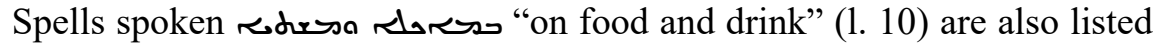
as a specific concern in the amulet. Again, Bohak's observations are pertinent:

Unlike the Syriac amulet, in the Pishra it is angels who are asked to dissolve the spells, so that a typical sequence runs as follows "If on food and drink they worked (witchcraft) upon him, Zarhiel will loosen him; and if on mustard and on a seed they worked (witchcraft) upon him, Qațiel will loosen him; and if on tail-fat and wax and bitumen and all (kinds of) oil and fat they worked (witchcraft) upon him, Zarqiel will loosen him". The specific methods of witchcraft supposedly used by the client's enemies show an exact overlap in the case of "food and drink"

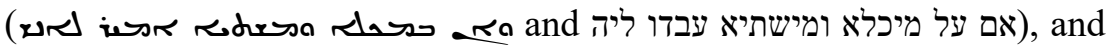
diverge in other instances, but the magical techniques listed by the Syriac text (writing on gold, brass, lead, leaves, and so on) are paralleled in numerous Jewish magical texts.

The format of "If a person worked witchcraft (on the client) by method $\mathrm{X}$, may he (the client) be loosened" recurs in medieval Jewish magical texts as well. In a long amulet found in the Cairo Genizah, the appeal is that "all types of witchcraft and all types of sorcery, and all evil writings, and all evil bindings that were done to (the two clients) or that will be done, whether by day or by night, whether in a tomb or under a tree, whether by food or by drink (בין במיכל בין במשקיי), whether in a home or in a field, whether under the moon or (under the stars), will be annulled and loosened". ${ }^{96}$

\footnotetext{
${ }^{95}$ GOLLANCZ 1912: xxxvii.

${ }^{96}$ Personal correspondence, Feb. 6, 2021. On the Cairo Genizah amulet, Cambridge University Library, T-S K 1.168, see SCHIFFMAN \& SWARTZ 1992: 149, 153.
} 
The text speaks of how بس山 ب. were released" (1. 14) from the fiery furnace (1. 15) (Dan. 3:13-30), a phrase also present in a Syro-Turkic amulet found in Qara Qoto by Piotr Kozlov (now in the Institute of Oriental Manuscripts, RAS) ${ }^{97}$ and a 19th c. Syriac amulet from Kurdistan published by Hunter. ${ }^{98}$

The second instance of deliverance from the Hebrew Bible is undoubtedly

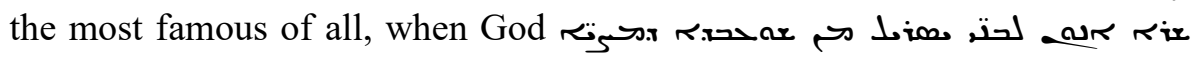
"set free the Sons of Israel from the subjugation of the Egyptians" (11. 1719), a rescue celebrated in both the Hebrew Bible (e.g. Psa. 78:12ff; 136:10ff) and the New Testament (e.g. Acts 7:17ff; Heb. 11:23ff).

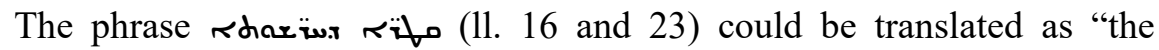
bonds of sorcery" or "the knots of witchcraft". It occurs once in the texts published by Gollancz, ${ }^{99}$ along with two occurrences of a similar phrase rdoriw r roor (meaning specifically "bonds" but not "knots"). ${ }^{100}$ The idea that "the sacred action of tying or untying a knot serves to establish or remove some restraint and that it has either a positive or a negative effect"101 is deeply rooted in magical literature from many different cultures, including the Mesopotamian matrix in which Aramaic magical traditions formed.

It is very common to include in Syriac amulets the various names of God found in the Hebrew Bible. ${ }^{102}$ Although such amulets usually include the

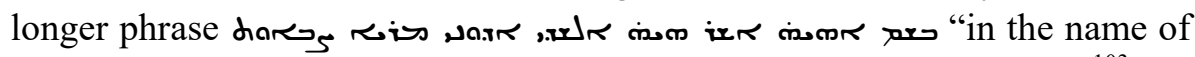
I AM WHO I AM, Almighty God [El Shaddai], Adonai, Lord of Hosts", ${ }^{103}$ our amulet mentions only ara "in the name of I AM WHO I AM"104 (Ex. 3:14) and دa: "כo "in the name of Adonai" (11. 21-22, 24).

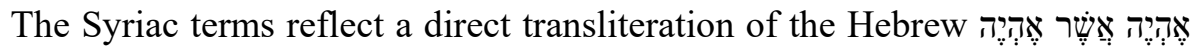
and

The two archangels "حصنص (Gabriel and Michael" (1. 25) are frequently mentioned together in Syriac prayer amulets, often along with

\footnotetext{
${ }^{97}$ SMELOVA 2015: 228.

${ }^{98}$ HUNTER 2009: 200.

${ }^{99}$ GOLLANCZ 1912: lxxiv, 78.

${ }^{100}$ Ibid.: xxvi, lv, 3, 30.

${ }^{101}$ PicCALUGa 2005: 5197.

102 HAZARD 1893: 285, 295; GollanCZ 1912: xxvi, xxvii, xxix, xxxi, xxxiii, xlvii, xlix, lvii, lxii, lxxiii, lxxv, lxxix; GigNOUX 1987: 11; HUNTER 1993: 251; HUNTER 1999: 167.

${ }^{103}$ GollanCZ 1912: xxvi, 2-3.

${ }^{104}$ On this title, see PAYNE SMITH 1879-1901: col. 46.
} 
other angels. ${ }^{105}$ Of the four classical archangels - Gabriel, Michael, Raphael and Uriel - only the first two are named in the Bible (Gabriel in Dan. 8:15, 16; 9:21; Luke 1:19, 26; Michael in Dan. 10:13, 21; Dan. 12:1; Jude 1:9; Rev. 12:7).

The nine ranks of angels are occasionally mentioned in Syriac amulets,

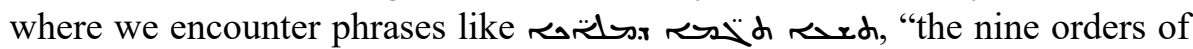
angels", ${ }^{106}$ but that phrase does not occur in our amulet. Instead, the names of the nine ranks in the angelic hierarchy are given in descending order:

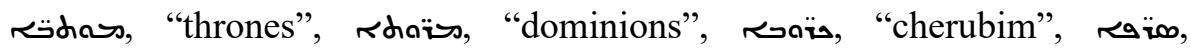

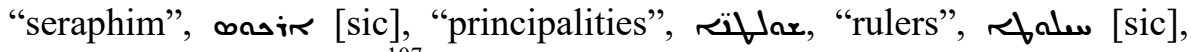

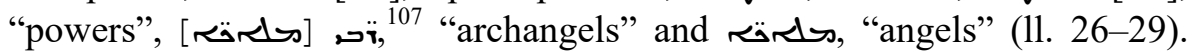
These terms also find their origins in the Bible (e.g. Ps. 148:2; Isa. 6:1-3; Ezek. 10:1-22; Rom. 8:38; Eph. 1:21; 3:10; 6:12; Col. 1:16; 2:10, 15; 1 Thess. 4:16; 1 Pet. 3:21-22; Jude 9).

Lists of the angelic ranks are found in early patristic and liturgical literature. Examples include the Apostolic Constitutions (4th c.); ${ }^{108}$ John Chrysostom's (d. 407) Homily Against the Anomoeans; ${ }^{109}$ the Mystagogical Catechesis V, attributed to either Cyril of Jerusalem (d. 386) or his successor John of Jerusalem (d. 417); ${ }^{110}$ and different versions of the Anaphoras of St. Basil and St. James ${ }^{111}$ (this list of sources is by no means comprehensive). It is commonly accepted that the author of the Corpus Areopagiticum (early 6th c.), referred to as Pseudo-Dionysius the Areopagite, was the first to develop a systematic structure of the angelical hierarchy in the treatise On the Celestial Hierarchy (hereafter: $\mathrm{CH}$ ), which involved three ranks with three angelic orders in each of them and which greatly influenced subsequent Christian writings. ${ }^{112}$

${ }^{105}$ GOLLANCZ 1912: xxix, xxxiii, xlviii, xlix, lxvi, lxxi, lxxv, lxxix, lxxxv; HunTER 2009: 201.

${ }^{106}$ GollanCZ 1912: 1xiv, lxxviii, 45, 82.

${ }^{107}$ As noted above, there seems to be an instance of haplography in the text here, with the scribe missing out one of two adjacent instances of the word sanc, "angels".

${ }^{108}$ Const. Apost. VII 35. 3 (9 ranks); VIII 12. 8 (10 ranks including Ages and Armies); VIII 12. 27 (11 ranks). MeTZGER 1985: III, 76, 182, 192.

${ }^{109}$ Contra Anom. II 279-280. MALINGRey 1970: 164.

${ }^{110}$ Cat. Myst. V 6.4-11 (9 ranks). PiÉDAGnel 1966: 154.

${ }^{111}$ FENWICK 1992: 88-89 (generally 9 ranks).

112 These ranks include: I) Seraphim (1), Cherubim (2), Thrones (3); II) Dominions (4), Powers (5), Authorities/Rulers (6); III) Principalities (7), Archangels (8), Angels (9) (CH VII-IX). See ARTHUR 2008: 43. 
The ranks are present in various pieces of Syriac literature, of different kinds and genres, from apocrypha to encyclopaedic works of the Syriac Renaissance. Below, we compare a few instances with the list found in our amulet. We have deliberately selected different literary forms and traditions (East Syriac and West Syriac; native Syriac works and those translated from Greek) to show their unity on the one hand and some differences in terminology and listing order on the other. 1) The Testament of Adam is an apocryphal compilation, thematically close to the Cave of Treasures and thought to have been originally composed in Syriac, which includes a section on the angelical hierarchy. ${ }^{113}$ 2) The Liber Patrum is a treatise dealing with both the angelic and the ecclesiastical hierarchy, influenced by Pseudo-Dionysius and attributed to the East Syriac author Simeon Shanqlawi (late 12th - early 13th cc.). ${ }^{114}$ 3) Pseudo-Dionysian ranks of angels also appear in a Syriac version of the treatise De gemmis ("On gemstones", since the ranks of angels are connected here to the gemstones of the ephod). The treatise is included in the so-called Syriac Masora, in its West Syriac form (probably early 11th c.). ${ }^{115}$ 4) Our last point of comparison is a list of angelic orders in the Pre-Sanctus (priest's prayer before the Sanctus) in the West Syriac version of the Anaphora of St. James. ${ }^{116}$ The mention of the celestial ranks here reflects the biblical context of the Sanctus hymn (Isa. 6:2-3).

\begin{tabular}{|c|c|c|c|c|}
\hline $\begin{array}{l}\text { Amulet, } \\
\text { ВДсэ-524 }\end{array}$ & $\begin{array}{l}\text { Testament } \\
\text { of Adam }\end{array}$ & $\begin{array}{c}\text { Liber } \\
\text { Patrum }\end{array}$ & $\begin{array}{c}\text { De gemmis } \\
\text { in the Syriac } \\
\text { Masora }\end{array}$ & $\begin{array}{c}\text { West Syriac } \\
\text { Anaphora } \\
\text { of St. James }\end{array}$ \\
\hline $\begin{array}{r}\text { thrones (3) } \\
\text { thro }\end{array}$ & 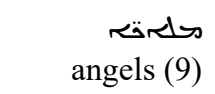 & 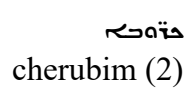 & $\begin{array}{r}\text { sitaphim (1) } \\
\text { seraphim }\end{array}$ & angels (9) \\
\hline $\begin{array}{r}\text { dominions (4) } \\
\text { doming }\end{array}$ & 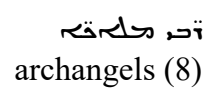 & Seraphim (1) & $\begin{array}{r}\text { cherubim (2) } \\
\text { حim }\end{array}$ & 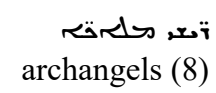 \\
\hline
\end{tabular}

${ }^{113}$ This section is found in one manuscript only, Vatican Library, Vat. sir. 164 (1702 AD). KMOSKO 1907: col. 1353-1360; see also RoBINSON 1982.

${ }^{114}$ Vatican Library, Vat. sir. 568, ff. 3r-7v; see also VosTÉ 1940: 11, 16-20. We are grateful to Fr. Aphrem Dawood who pointed out this work and manuscript to us.

${ }^{115}$ British Library Add. 7183, f. 131r; see also RosEn \& ForSHALl 1838: 70. The information on this treatise and manuscript was kindly provided by Jonathan Loopstra, who is preparing an edition and translation of it.

${ }^{116}$ HeIMING 1953: 142. We quote here the list of angelic ranks as it is preserved in the long version of the Anaphora (according to British Library Add. 14499, 10th century). We acknowledge the generous help and valuable advice of Kees den Biesen.

${ }^{117}$ Numbers in parentheses indicate the order of the ranks according to $\mathrm{CH}$. 


\begin{tabular}{|c|c|c|c|c|}
\hline $\begin{array}{l}\text { Amulet, } \\
\text { ВДсэ-524 }\end{array}$ & $\begin{array}{l}\text { Testament } \\
\text { of Adam }\end{array}$ & $\begin{array}{c}\text { Liber } \\
\text { Patrum }\end{array}$ & $\begin{array}{c}\text { De gemmis } \\
\text { in the Syriac } \\
\text { Masora }\end{array}$ & $\begin{array}{c}\text { West Syriac } \\
\text { Anaphora } \\
\text { of St. James }\end{array}$ \\
\hline $\begin{array}{r}\text { حَّär } \\
\text { cherubim (2) }\end{array}$ & 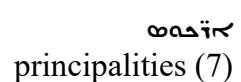 & $\begin{array}{l}\text { Särö } \\
\text { thrones (3) }\end{array}$ & $\begin{array}{l}\text { ridors } \\
\text { thrones (3) }\end{array}$ & $\begin{array}{r}<\text { idinalies (7) } \\
\text { principalities }\end{array}$ \\
\hline $\begin{array}{r}\text { متحه } \\
\text { Seraphim (1) }\end{array}$ & $\begin{array}{l}\text { चौ } \\
\text { rulers (6) }\end{array}$ & $\begin{array}{r}\text { rdäars } \\
\text { dominions (4) }\end{array}$ & $\begin{array}{r}\text { rdiaiss } \\
\text { dominions (4) }\end{array}$ & $\begin{array}{l}\text { عقله } \\
\text { rulers (6) }\end{array}$ \\
\hline $\begin{array}{r}\text { on } \\
\text { principalities (7) }\end{array}$ & powers (5) & powers (5) & $\begin{array}{l}\text { rdate } \\
\text { powers (5) }\end{array}$ & $\begin{array}{r}\text { sdiäs } \\
\text { thrones (3) }\end{array}$ \\
\hline 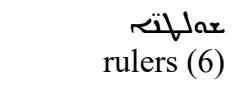 & $\begin{array}{r}\text { rdä̈s } \\
\text { dominions (4) }\end{array}$ & $\begin{array}{r}\text { عقله (6) } \\
\text { rulers (6) }\end{array}$ & 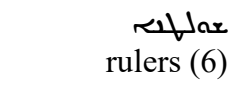 & $\begin{array}{r}\text { rdäs } \\
\text { dominions (4) }\end{array}$ \\
\hline powers (5) & $\begin{array}{l}\text { Sadian } \\
\text { thrones (3) }\end{array}$ & $\begin{array}{r}\text { אשتصم } \\
\text { principalities (7) }\end{array}$ & $\begin{array}{r}\text { कrarir } \\
\text { principalities (7) }\end{array}$ & $\begin{array}{l}\text { wers (5) } \\
\text { powers }\end{array}$ \\
\hline 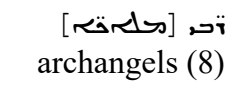 & $\begin{array}{r}\text { متحس } \\
\text { seraphim (1) }\end{array}$ & 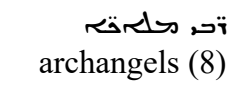 & 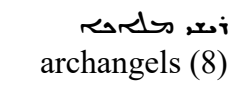 & $\begin{array}{r}\text { عتمحسم (2) } \\
\text { cherubim }\end{array}$ \\
\hline $\begin{aligned} \text { هân (9) } \\
\text { angels (9) }\end{aligned}$ & $\begin{array}{r}\text { هتمحن } \\
\text { cherubim (2) }\end{array}$ & 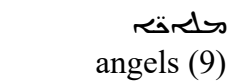 & $\begin{aligned} \text { angels (9) } & \text { ands }\end{aligned}$ & $\begin{array}{r}\text { متحس } \\
\text { seraphim (1) }\end{array}$ \\
\hline
\end{tabular}

As can be seen from the above table, De gemmis seems to preserve the Pseudo-Dionysian order most accurately, although Liber Patrum is very close, differing only in the order of cherubim and seraphim. Interestingly, the Testament of Adam demonstrates the ranks in the reverse sequence, which is also partially reflected in the Anaphora. There are also some differences in terminology. Thus, the loanword (Greek ảpqaí) is not present in the West Syriac Anaphora, which uses Syriac rorincipalities") instead. Our Turfan amulet lists the angelic hosts in random order. Apparently, it was not the intention of the scribe or compiler to follow any established sequence; most likely, he did not have any literary template in front of him, but rather relied on oral tradition.

It is hardly surprising to find a reference in the amulet to rotosded "the praiseworthy Trinity of the Father, of the Son and of the Holy Spirit" (11. 34-36). Indeed, the invocation of the Trinity in Syriac amulets is extremely common (nearly every example published by Gollancz starts with the phrase).

Also foundational to the Christian tradition is a reliance on and reverence for علغنت "the holy apostles" (1. 37), whose efforts at turning the nations away from demonic worship is viewed as a template for the work of

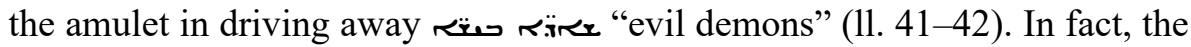
amulet uses three different terms to describe the spiritual adversaries that it 


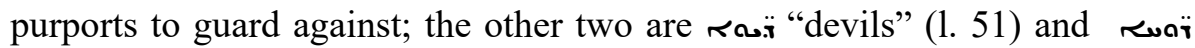
rdre "evil spirits" (1. 52).

In addition to the sorcery, stratagems and contrivance(s) of demons, the

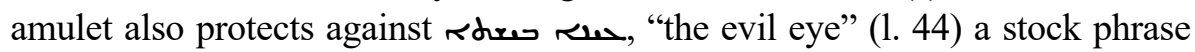
found in these Syriac amulets ${ }^{118}$ which reflects a commonly-held belief from antiquity onward "that some persons may produce malevolent effects on others by looking at them, based on the supposed power of some eyes to bewitch or harm by glance". "demons of lunacy" (1. 44), literally "sons of the roof", also known as rooftop demons and attested in Hebrew sources, as well as "Mandaic, Syriac and various Babylonian Aramaic idioms". ${ }^{120}$ The term refers to epilepsy, as is clear

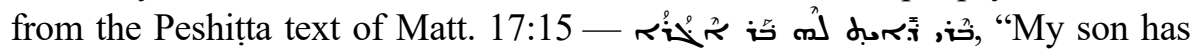
epilepsy". The equation with lunacy is standard in late antique texts.

Our amulet focuses extensively on the healings and exorcisms of Christ (11. 49-52), with a series of clauses in which (in contrast to standard Syriac syntax) the noun precedes the verb. Could this indicate some form of language interference from Uyghur, which has verb-final syntax? Significant space is given to the New Testament pericope of the expelling of legion [of evil spirits]" from the aforementioned Gadarene demoniac (11. 5557). The vocabulary of the amulet closely follows the Peshitta, particularly

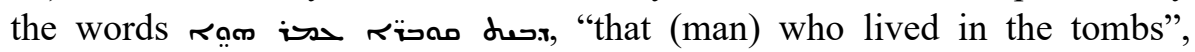
quoting the text in Mark 5:3, حُدِّن (cf. Luke 8:27).

In the sealing section of the amulet, two interesting references are made:

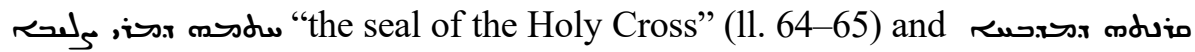
ఒm "the horns of the glorious altar" (11. 66-67). The former is presented as Mar Șaliba, which refers not to a saint, as one might expect — the title, Sin Mar is typically used for saints and bishops and Saliba, meaning "cross", is a common name in the Syriac tradition - but rather to the cross itself, which is personalized by adding Mar in front of it in colloquial usage. Indeed, some Syriac manuscripts refer to the Feast of the Exaltation of the Holy Cross in the liturgical calendar of the Church of the East (September 13th) as "Mar Saliba". ${ }^{121}$ However, in this case, such a personification seems

118 HAZARD 1893: 285, 291; Gollancz 1912: xl, xlviii, lviii, lxx-lxxi, lxxxii-lxxxiii; HUNTER 1999: 167.

${ }^{119}$ NOY 2007: 584.

${ }^{120}$ KWASMAN 2007: 165-169, 183.

${ }^{121}$ Our thanks to His Holiness Mar Awa III and Sergey Minov for their help in deciphering the meaning of this phrase, including references. See VAN DER PLOEG 1983: 89. 
to testify to popular practice rather than the formal way of referring to the Holy Cross.

Regarding the horns of the altar, Bohak observes that

the same phrase occurs in an ancient Jewish amulet, as part of a long series of sacred objects, "and by the rod of Moses, and by the golden plate of Aaron the high priest, and by the signet-ring of Solomon, and by the [shield] of David, and by the horns of the altar (ובקרנתה דמדבחא), and by the Name of the living and existent God". ${ }^{22}$

This expression alludes to particular places in the Old Testament where the altar is described as having one horn on each of its four corners (Ex. 27:2; 38:2); the practice of blood sacrifice on the altar horns (Ex. 29:12; Lev. $4: 7 ; 8: 15)$ made them, along with the rest of the altar, objects of extreme holiness and mercy. The example of biblical personalities, such as Adonijah and Joab (1 Kings 1:50-51;2:28), who took hold of the horns of the altar as a means of appealing for mercy, explains the presence of this symbol in the amulet.

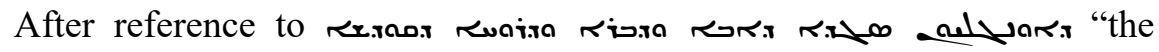
venerable Gospel of the Father, the Son and the Holy Spirit" (11. 68-70), the

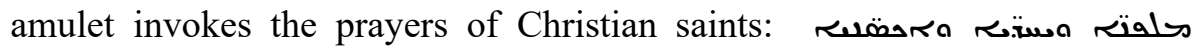
محسقه "teachers, solitaries, pilgrims and ascetics" (11. 71-72). The phrase , כ5 "by the prayer of the Blessed Holy Lady Mary" (11. 72-74) is exceedingly common in Syriac prayer amulets, especially at the end of the text. ${ }^{123}$ The words ruess m mse, "the mother of Christ" (1. 74), which constitute clear evidence of the origins of the amulet within the Church of the East, occur less frequently in Syriac amulets. ${ }^{124} \mathrm{We}$ do, however, find them in several Turfan texts: remnants of a Syriac prayer booklet to the Virgin Mary (SyrHT 279, SyrHT 280), two fragments from the Syriac liturgical text designated as Hudra N (SyrHT 337, n421) and another Syriac liturgical text with Sogdian instructions for the priest (n395). ${ }^{125}$

\footnotetext{
${ }^{122}$ Personal correspondence, Feb. 6, 2021. The Jewish amulet was published in NAVEH \& SHAKED 1993: 91-95.

${ }^{123}$ HaZARD 1893: 286, 289, 292, 294; GollanCz 1912: xxvi, xxvii, xxix, xxx, xxxi, xxxvi, xxxix, xl, xli, xlii, xlv, 1, lii, liii, lxii, lxv, lxvii, lxxi, lxxvi, lxxx, lxxxi, lxxxii; HunTER 1987: 101, 103; HUNTER 1993: 251, 252; HUNTER 1999: 167, 169, 170, 171. Occasionally the sim-

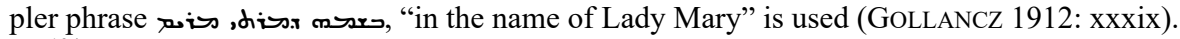

${ }^{124}$ GOLLANCZ 1912: 1xv, lxvii.

${ }^{125}$ HuNTER \& DiCKENS 2014: 264, 265, 307-308, 402, 412.
} 


\section{Connection with SyrHT 274-276}

A case can be made for connecting the scroll now in the Hermitage with three Syriac fragments in the Berlin Turfan Collection (Staatsbibliothek zu Berlin - Preußischer Kulturbesitz), glassed together and assigned the new signature numbers SyrHT 274, SyrHT 275 and SyrHT 276. ${ }^{126}$ The visible text and translation are as follows (they are affixed to yellow pasteboard, so there is no verso, as is the case with the Hermitage scroll).

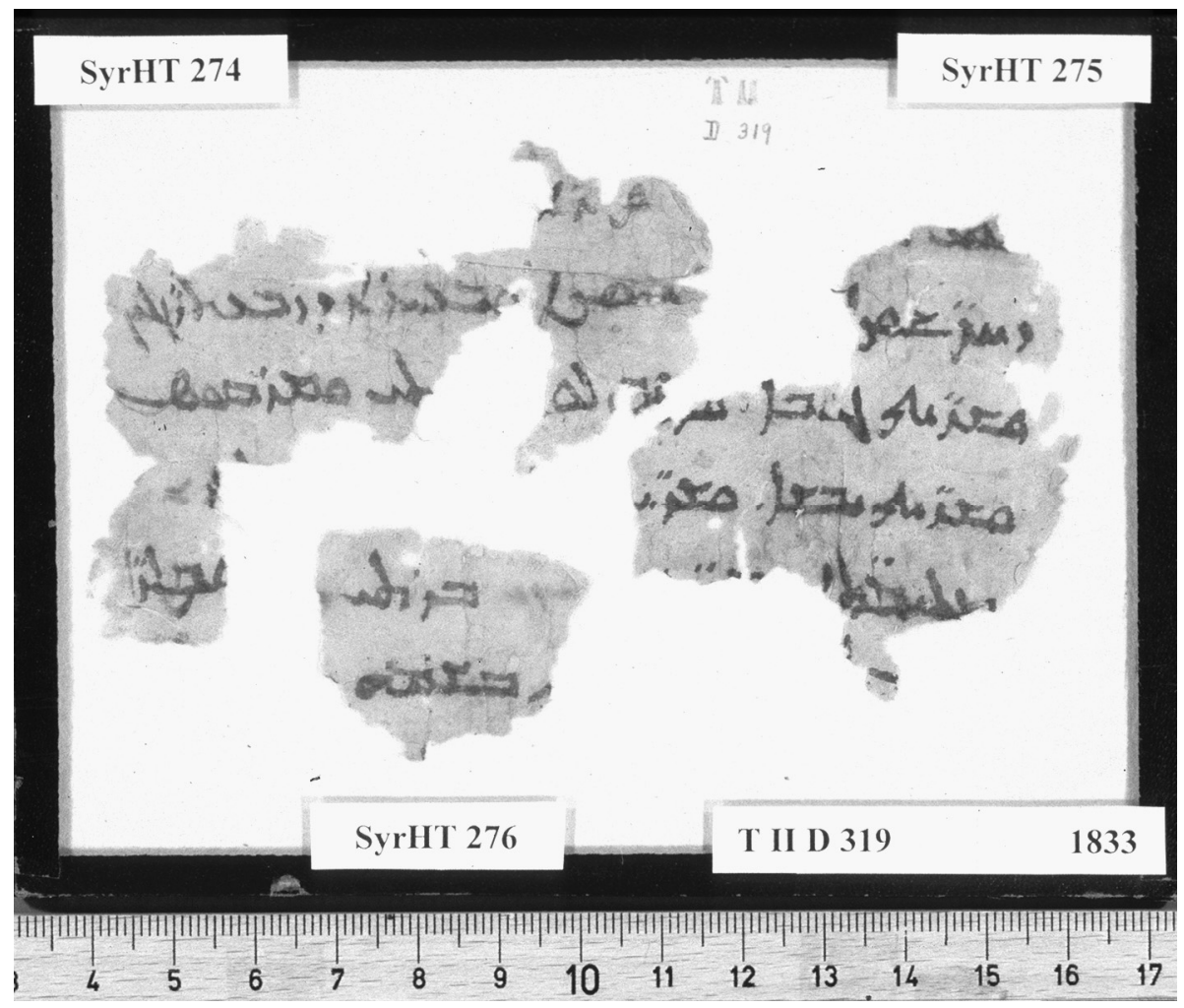

Pl. 8. SyrHT 274, 275, 276.

(C) Depositum der BERLIN-BRANDENBURGISCHEN AKADEMIE DER WISSENSCHAFTEN in der STAATSBIBLIOTHEK ZU BERLIN Preußischer Kulturbesitz, Orientabteilung

\footnotetext{
${ }^{126}$ Prayer-amulet D in HunTER \& DiCKENS 2014: 453.
} 


\section{SyrHT 274:}

Syriac Text

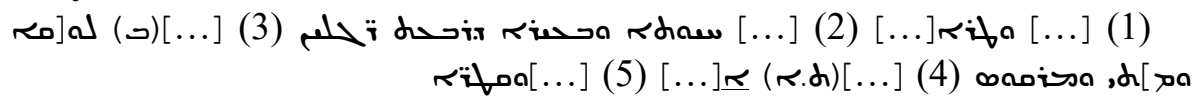

Translation

(1) And it has struck [...] (2) animals and cattle that have put down feet $[\ldots]$ (3) Lu[ke, Ma]tthew and Mark [...] (4) [...] (5) and knots [...]

\section{SyrHT 275:}

\section{Syriac Text}

(4) $[\ldots$ d..

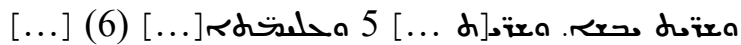

\section{Translation}

(1) Jesus [...] (2) of sorceries [...] (3) and loosened the well [...] and [...] and loosened $[\ldots]$ (4) and loosened the dry land and $[\ldots]$ loosened $[\ldots]$ (5) and the young [...]

\section{SyrHT 276:}

\section{Syriac Text}

\section{Translation}

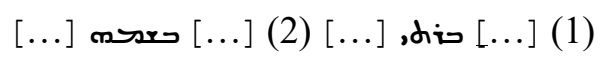

(1) $[\ldots]$ My daughter... (2) in his name...

Could these fragments come from the scroll, the beginning and end of which are now missing? Indeed, there are a number of common features that can be noted:

1. The original find number given to these three fragments by the Second Turfan Expedition is T II D 319. Thus, as noted at the beginning of this article, they were also discovered by von Le Coq in Dakianus-shahri.

2. In terms of paleography, the scribal hand represented in these fragments can be compared favourably with the last hand on the amulet (11. 69-78). 
Notable common features include distinctive shapes of the letters $x$ (throughout ВДсэ-524 and the Berlin fragments), $;$ (particularly in ВДсэ524, 1. 76-77 and SyrHT 275, 1. 2-4) and $\alpha$ (ВДсэ-524, 11. 70, 72 and SyrHT 275, 1. 3-4), along with the plural marker seyame (throughout ВДсэ-524 and the fragments), and particularly the ligature rd (ВДсэ-524, 1. 73, SyrHT 274, 1. 2, SyrHT 275, 1. 2); on the use of the latter throughout the scroll, see the Introduction above.

3. As noted above, like the scroll, the fragments are one-sided and are written on a similar type of cotton paper. The width of the largest fragment SyrHT 274 is $7.5 \mathrm{~cm}$, which roughly corresponds to the width of the scroll, although we cannot rule out the possibility that there was more text on the right-hand side.

4. The language of the fragments fits nicely with that in our amulet, particu-

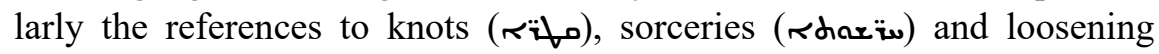
things ( $\left(\alpha_{\text {r }}\right.$ ). In terms of phraseology, there is nothing in these fragments that would disqualify them from having originally come from the scroll. Nonetheless, rather than the word commonly used in the amulet ridr ("may he be loosened"), we find instead another form of the same verbal stem. Neither can we explain the word ("my daughter") that appears after the rubric (SyrHT 276, 1. 1), if the client is a male, as is clear from the scroll.

5. Finally, there are remnants of faded rubrics visible in two places (SyrHT 274, 1.4 and SyrHT 276, 1. 1) that might match portions of the rubric on the amulet (in particular, the initial $\prec$ and possibly a visible on SyrHT 274).

Thus, we can confirm that the paleographical features and some common vocabulary may well testify to the Berlin fragments and the Hermitage scroll belonging together. However, there still remain unanswered questions regarding their relationship.

\section{Connection with Qara Qoto manuscript H彩101}

In the course of preparing this article for publication, the authors became aware of some striking similarities between the amulet discussed above and another text, H彩101, discovered in Qara Qoto by the 1983-1984 expedition 
of the Institute of Cultural Relics, Inner Mongolia Academy of Social Sciences. Although several of the texts unearthed are in Syriac script, only one is actually in the Syriac language (the others are in Old Uyghur). The Syriac text, which is very difficult to decipher due to damage from fold lines and insects, as well as smudged ink, was examined by Shinichi Muto, who initially considered it to be a theological tract, based on the discernible words. ${ }^{127} \mathrm{He}$ later adjusted this evaluation, viewing the text as having something to do with exorcism, albeit divorced from earlier Syriac literature, due to its "magical" terminology. ${ }^{128}$

We can now confirm that $\mathrm{H}$ 彩101 from Qara Qoto is also an amulet, made for a different client, which shares much of the same terminology as that found in the Hermitage amulet. Paleography-wise, both amulets feature a similar writing of East Syriac origin. H彩101 is thought to date from the Mongol period (13th-14th cc.); our conjecture is that the Hermitage scroll from Turfan belongs to the same period. That H彩101 is, like the Hermitage scroll amulet, also concerned with protective magic is now beyond doubt in our minds. The similarities between the two texts are such that whole sections of one are duplicated (frequently word for word) in the other. Although we cannot say at this point what the exact relationship between the two texts is, there is no question that some sort of relationship does exist (most likely, they both descend from a common version of the text). This is a line of inquiry that we intend to explore in a future article, in which we will present a comparison of the two.

\section{Conclusions}

The Syriac amulet discussed in this article is notable for a number of reasons. It is one of the longer Christian texts found at Turfan (despite missing its beginning and ending) and is unique in its format - no other scroll amulet has been unearthed there. Also distinctive is the fact that the main body of the text is now housed in St. Petersburg, whereas fragments that were likely parts of that same text reside in Berlin.

The text is also significant in terms of the insights it gives into the various cultural influences present in the Christian community at Turfan. Although

\footnotetext{
${ }^{127}$ Muto 2013.

${ }^{128}$ Muto 2016; see also SMELOVA 2015: 232-233.
} 
the amulet was obviously written in Turfan, as the Uyghur name of the client makes clear, its appearance there is the culmination of a long trajectory of magical texts in various Aramaic dialects (e.g. Jewish Aramaic, Mandaic and Syriac), ultimately stretching back to the time of ancient Assyria and Babylonia, where the origins of so many magical texts can be found. The many parallels between our amulet and magical texts found throughout the Mediterranean and Mesopotamia (dating from Late Antiquity to the 19th c.) connect the amulet with a broader family of magical texts that have common themes and terminology.

Thus, we are struck by reflections of both Judaism and Christianity, traces of both the Hebrew Bible and the New Testament, with historiolae selected from each. The fiery furnace, slavery to the Egyptians and the archangels Michael and Gabriel from the former are complemented by the miracles of Christ, the witness of the apostles and the nine ranks of angels rooted in the latter. The amulet invokes the Old Testament names of I AM WHO I AM and Adonai along with the New Testament Trinitarian formula. In parallel with references to the evil eye and the demons of lunacy, both also found in Jewish magical texts, the healings and exorcism of Christ are highlighted as precursors of the authority with which our amulet is able to loosen the client from the effects of evil.

In addition to the general Christian nature of the text, the amulet has several specific connections with the Church of the East, the Christian community which was predominant in Turfan. In the sealing section near the end of what remains of the scroll, in addition to the horns of the altar, the seal of Mar Șaliba is referred to, by which is understood the cross itself, celebrated during the Church's Feast of the Exaltation of the Holy Cross. Further on in the text, we encounter Mary referred to as the Mother of Christ, a term that is deeply embedded in the Antiochian exegetical tradition that the Church of the East champions.

Despite the amulet's Near Eastern pedigree, linking it with Jewish and Christian ideas from Late Antiquity, the Uyghur Christian community where the text was copied and used appears to have left several marks on the artefact we are concerned with. It is evident from the multiple spelling errors -

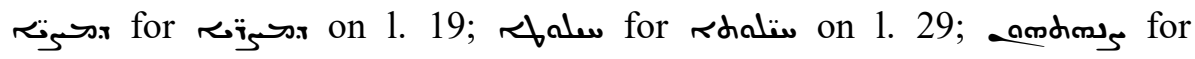
and on 1.

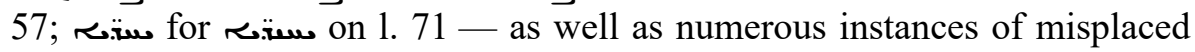
or missing a, "and", that the scribe or scribes involved in copying the amulet 
were not native speakers of Syriac. Moreover, as noted above, the series of clauses in 11. 49-52, all following a noun-verb pattern (rather than the typical Syriac syntax of verb-noun) may indicate grammatical interference on the part of the Uyghur language. It also seems possible that there is phonological influence in the way that some Syriac words are written, specifically in the likely assimilation of /d/ to /t/ in sudre (in place of sexdre, "were cleansed"). This phonological assimilation is all the more likely assuming the text was being spoken aloud by a Uyghur native speaker in some sort of exorcism ritual.

Finally, we may note the long journey of the text and its antecedents, from its origins in the Ancient Near Eastern matrix, though the Mesopotamian heartland of Syriac Christianity, eastward through Persia and along the Silk Road network plied by monastic and mercantile adherents of the Church of the East, all the way to the heart of the Uyghur Kingdom on the borders of the Chinese Tang Empire (later to be incorporated into the Mongol Empire). Finally, after centuries of lying beneath the Central Asian sands, it was dug up by German explorers and carried back to Europe, where it survived the bombings of the Second World War and from whence it was taken once again, to be deposited in its new home in the Hermitage.

\section{References}

ARTHUR, Rosemary A. 2008: Pseudo-Dionysius as Polemicist: The Development and Purpose of the Angelic Hierarchy in Sixth Century Syria (Ashgate New Critical Thinking in Religion, Theology and Biblical Studies). Aldershot: Ashgate.

BALL, Warwick 2000: Rome in the East. The transformation of an empire. London \& New York: Routledge.

BoHAK, Gideon 2019: “An Ancient Babylonian Text on a Modern Jewish Amulet”. Windows on Jewish Worlds: Essays in Honor of William Gross Collector of Judaica, on the Occasion of his Eightieth Birthday. Ed. by Shalom Sabar, Emile Schrijver and Falk Wiesemann. Zutphen: Walburg Pers: 350-361.

BorovKov, Aleksandr K. 1959: Uzbeksko-russkii slovar [Uzbek-Russian dictionary]. Ed.-inchief Aleksandr Konstantinovich Borovkov. Moscow: Gosudarstvennoe izdatelstvo inostrannykh i natsionalnykh slovarei.

Boyle, John Andrew 1958: The History of the World-Conqueror (2 vols). Trans. by John Andrew Boyle. Manchester: Manchester University Press.

Clauson, Gerard 1972: An Etymological Dictionary of Pre-Thirteenth Century Turkish. Oxford: Clarendon Press. 
De BruYn, Theodore 2017: Making Amulets Christian: Artefacts, Scribes, and Contexts (Oxford Early Christian Studies). Oxford: Oxford University Press.

DerRETT, John Duncan Martin 1983: "Binding and Loosing (Matt 16:19; 18:18; John 29:23)". Journal of Biblical Literature 102.1: 112-117.

DiCKENS, Mark 2013: "Scribal Practices in the Turfan Christian Community". Journal of the Canadian Society for Syriac Studies 13: 3-28.

DiCKENS, Mark 2016: "Biblical Fragments from the Christian Library of Turfan, an Eastern Outpost of the Antiochian Tradition". In: The School of Antioch: Biblical Theology and the Church in Syria (The Bible in the Christian Orthodox Tradition, vol. 7). Ed. by Vahan Hovhanessian. Bern: Peter Lang: 19-47.

Dickens, Mark \& Sims-Williams, Nicholas 2012: "Christian Calendrical Fragments from Turfan". In Living the Lunar Calendar. Ed. by Jonathan Ben-Dov, Wayne Horowitz \& John M. Steele. Oxford: Oxbow Books: 269-296.

EMERTON, John Adney 1962: "Binding and Loosing-Forgiving and Retaining". Journal of Theological Studies 13.2: 325-331.

FARAJ, Ali H. 2010: “An Incantation Bowl of Biblical Verses and a Syriac Incantation Bowl for the Protection of a House". CAMSEMUD 2007: Proceedings of the 13th Italian Meeting of Afro-Asiatic Linguistics (History of the Ancient Near East / Monographs, Vol. X). Ed. by Frederick Mario Fales \& Giulia Francesca Grassi. Padova: S.A.R.G.O.N. Editrice e Libreria: 205-212.

FEnwick, John R.K. 1992: The Anaphoras of St Basil and St James: An Investigation into their Common Origin. Rome: Pontificium Institutum Orientale.

GARKAVETS, Aleksandr 2019: Codex Cumanicus: vtoroe polnoe izdanie [Codex Cumanicus: the second complete edition]. Almaty: Almaty-Bolashak.

GignOuX, Philippe 1987: Incantations magiques syriaques. Louvain: Peeters.

Gollancz, Hermann 1912: The Book of Protection, Being a Collection of Charms. London: Oxford University Press.

GRønBECH, Kaare 1942: Komanisches Wö̈terbuch: Türkischer Wortindex zu Codex Cumanicus (Monumenta Linguarum Asiae Maioris, Subsidia, vol. 1). Kopenhagen: Einar Munksgaard.

GRÜNWEDEL, Albert 1906: Bericht uber archä̈logische Arbeiten in Idikutschari und Umgebung im Winter 1902-1903 (Abhandlungen der philosophisch-philologischen Classe der Königlich Bayerischen Akademie der Wissenschaften. 24.1). Munich: Verlag der K.B. Akademie der Wissenschaften.

GRÜNWEDEL, Albert 1920: Alt-Kutscha. Archä̈logische und religionsgeschichtliche Forschungen an Tempera-GemaIden aus Buddhistischen Hohlen der ersten acht Jahrhunderte nach Christi Geburt. Berlin: Otto Elsner Verlagsgesellschaft.

Harviainen, Tapani 1978: “A Syriac Incantation Bowl in the Finnish National Museum, Helsinki”. Studia Orientalia 51.1: 1-29.

HAZARD, Willis Hatfield 1893: “A Syriac Charm”. In: Journal of the American Oriental Society 15: 284-296.

HeImING, Odilo 1953: “Anaphora Syriaca Sancti Iacobi fratris Domini”. In: Anaphorae Syriacae, vol. 2.2. Rome: Pontifical Institute of Oriental Studies: 109-179. 
HiERS, Richard H. 1985: “'Binding' and 'Loosing': The Matthean Authorizations”. Journal of Biblical Literature 104.2: 233-250.

Hopkirk, Peter 2006 (1st ed. 1980): Foreign Devils on the Silk Road. The Search for the Lost Treasures of Central Asia. London: John Murray.

HunTER, Erica C.D. 1987: "Saints in Syriac Anathemas: A Form-Critical Analysis of Role". Journal of Semitic Studies 32.1: 83-104.

HunTER, Erica C.D. 1990: "Genres of Syriac Amulets: A Study of Cambridge MS. Syr. 3086”. In: V Symposium Syriacum, 1988 (Orientalia Christiana Analecta 236). Ed. by René Lavenant. Rome: Pontificio Institutum Studiorum Orientalium: 355-368.

HunTER, Erica C.D. 1993: “A Scroll Amulet from Kurdistan”. Aram 5: 243-254.

HunTER, Erica C.D. 1999: “Another Scroll Amulet from Kurdistan," in After Bardaisan: Studies in Continuity and Change in Syriac Christianity in Honour of Professor Han J.W. Drijvers (Orientalia Lovaniensia Analecta 89). Ed. by Gerrit J. Reinink \& Alexander Cornelis Klugkist. Leuven: Peeters: 161-172.

HunTER, Erica C.D. 2009: "Magic and Medicine amongst the Christians of Kurdistan". In: The Christian Heritage of Iraq (Gorgias Eastern Christian Studies 13). Ed. by Erica C.D. Hunter. Piscataway, NJ: Gorgias Press: 187-202.

HunTER, Erica C.D. 2013: "Traversing Time and Location: A Prayer-Amulet of Mar Tamsis from Turfan". In: From the Oxus River to the Chinese Shores: Studies on East Syriac Christianity in China and Central Asia (Orientalia-Patristica-Oecumenica, vol. 5). Ed. by Li Tang \& Dietmar W. Winkler. Wien: LIT Verlag: 25-41.

HunTER, Erica C.D. 2017: "Syriac Manuscripts from Turfan: Public Worship and Private Devotion". In From Ancient Manuscripts to Modern Dictionaries: Select Studies in Aramaic, Hebrew, and Greek (Perspectives on Linguistics and Ancient Languages 9). Ed. by Tarsee Li \& Keith Dyer. Piscataway, NJ: Gorgias Press: 77-96.

HunTER, Erica C.D. 2018: "Syriac Prayer-Amulets from Turfan”. The Harp 33: 413-431.

Hunter, Erica C.D. \& Dickens, Mark 2014: Syrische Handschriften. Teil 2. Syriac Manuscripts from the Berlin Turfan Collection (Verzeichnis der Orientalischen Handschriften in Deutschland 5,2). Stuttgart: Franz Steiner.

KATANOv, Nikolai F. 1893-1894: "Tatarskie skazaniia o semi spiashchikh otrokakh" [Tatarian legends on the Seven Sleepers]. Zapiski Vostochnogo otdeleniia Imperatorskogo Russkogo Archeologicheskogo obshchestva [Proceedings of the Oriental department of the Imperial Russian Archaeological society], 8(3-4): 223-245.

Kiliç Cengiz, Ayşe \& Turanskaia, Anna A. 2019: "Drevneuigurskie fragmenty Sitātapatrā dhāraṇī v kollektsii Gosudarstvennogo Ermitazha [Old Uyghur fragments of Sitātapatrā dhāraṇi in the collection of the State Hermitage Museum]". Pismennye pamiatniki Vostoka 4 (issue 43): 5-23.

Kmosko, Michael 1907: “Testamentum patris nostri Adam”. Ed. by M. Kmosko. In: Patrologia Syriaca 1.2. Paris: Firmin-Didot et socii, col. 1307-1360.

KWASMAn, Theodore 2007: “The Demon of the Roof". In: Disease in Babylonia (Cuneiform Monographs 36). Ed. by Irving L. Finkel \& Markham J. Geller. Leiden: Brill: 160-186.

LE CoQ, Albert von 1926: Buried Treasures of Chinese Turkestan: an Account of the Activities and Adventures of the Second and Third German Turfan Expeditions. Trans. by Anna Barwell. London: George Allen \& Unwin. 
Malingrey, Anne-Marie 1970: Jean Chrysostome. Sur l'incompréhensibilité de Dieu. Tome 1 (Homélies I-V) (Sources Chrétiennes, 28bis). Ed. by A.M. Malingrey Paris: Les éditions du CERF.

MeTZGer, Marcel 1985: Les Constitutions Apostoliques. Tome 3: Livres VII et VIII (Sources Chrétiennes, 336). Ed. by M. Metzger. Paris: Les éditions du CERF.

Montgomery, James A. 1918: "A Syriac Incantation Bowl with Christian Formula”. The American Journal of Semitic Languages and Literatures 34.2: 137-139.

Muto, Shinichi 2013: "The Triune God in the Tripartite World in a Syriac Manuscript found at Khara-Khoto". In: From the Oxus River to the Chinese Shores: Studies in East Syriac Christianity in China and Central Asia (Orientalia-Patristica-Oecumenica, vol. 5). Ed. by Li Tang \& Dietmar W. Winkler. Wien: LIT Verlag: 381-386.

Muto, Shinichi 2016: "The Exorcism in the Newly Found Khara-Khoto Syriac Document". In: Winds of Jingjiao: Studies on Syriac Christianity in China and Central Asia (Orientalia-Patristica-Oecumenica, vol. 9). Ed. by Li Tang \& Dietmar W. Winkler. Wien: LIT Verlag: 147-151.

NaveH, Joseph \& Shaked, Shaul 1985: Amulets and Magic Bowls: Aramaic Incantations of Late Antiquity. Jerusalem \& Leiden: The Magnes Press \& E.J. Brill.

NAVEH, Joseph \& SHAKED, Shaul 1993: Magic Spells and Formulae: Aramaic Incantations of Late Antiquity. Jerusalem: The Magnes Press.

Noy, Dov 2007: "Evil Eye”. In: Encyclopaedia Judaica, 2 ed., vol. 6: 584-585.

PAikova, Aza V. 1983: "Tunisskaia versiia legendy o semi spiashchikh otrokakh Efesskikh" [A Tunisian version of the legend on the Seven Sleepers of Ephesus]. In: Pismennye pamiatniki i problemy istorii kultury narodov Vostoka [Literary monuments and problems of history and culture of the East]. Moscow: Nauka, Glavnaia redaktsiia vostochnoi literatury: $167-174$.

PAiKova, Aza V. 1990: Legendy i skazaniia v pamiatnikah siriiskoi agiografii [Legends and tales in Syriac hagiography] (Palestinskii sbornik 30(93). Ed. by Elena N. Meshcherskaya. Leningrad: Nauka, Leningradskoe otdelenie.

PARRY, Ken 2012: "Reflections on a Silk Fragment from Toyuq: Christian or Manichaean?" Journal of Inner Asian Art and Archaeology, 7: 167-192.

PAyne SMith, Robert 1879-1901: Thesaurus Syriacus (2 vols.). Oxford: Clarendon Press.

PChelin, Nikolai G. \& Raschmann, Simone-Christiane 2016: "Turfan Manuscripts in the State Hermitage - a Rediscovery". Written Monuments of the Orient, 4: 3-43.

Peshchery tyciachi Budd 2008: Rossiiskie Ekspeditsii na Shelkovom Puti. K 190-letiiu Aziatskogo Muzeia. Katalog vystavki [The Caves of One Thousand Buddhas: Russian Expeditions on the Silk Route. On the occasion of 190 years of the Asiatic Museum. Exhibition catalogue]. St. Petersburg: The State Hermitage Publishers.

Piccaluga, Giulia 2005: "Knots”. Encyclopedia of Religion, 2 ed., vol. 8: 5196-5199.

Piedagnel, Auguste 1966: Cyrille de Jérusalem. Catéchèses Mystagogiques (Sources Chrétiennes, 126). Ed. by A. Piédagnel. Paris: Les éditions du CERF.

QAZVInI, Mīrzā Muḥammad 1912: Tärì̄kh-i-Jahān-Gushā of 'Alä̉u 'd-dīn 'Ațā-Malik-iJuwaynī, Part I (E.J.W. Gibb Memorial, Vol. XVI,1). Ed. by Mīrzā Muḥammad Qazvīn̄̄. Leyden: E.J. Brill. 
RÁSONYI, Lászlo \& BASKI, Imre 2007: Onomasticon Turcicum: Turkic Personal Names (2 vols) (Indiana University Uralic and Altaic Series, Vol. 172/I \& II). Bloomington: Indiana University.

REBIGER, Bill 2017: “'Write on Three Ribs of a Sheep': Writing Materials in Ancient and Mediaeval Jewish Magic”. In: Jewish Manuscript Cultures: New Perspectives (Studies in Manuscript Cultures 13). Ed. by Irina Wandrey. Berlin: De Gruyter: 339-359.

RoBinson, Stephen Edward 1982: The Testament of Adam: an examination of the Syriac and Greek traditions (Dissertation series (Society of Biblical Literature), 52). Chico: Scholars Press.

Rosen, Friedrich \& Forshall, Josiah 1838: Catalogus codicum manuscriptorum orientalium qui in Museo britannico asservantur. Pars 1: Codices syriacos et carshunicos amplectens. London: Impensis Curatorum Musei Britannici.

Schiffman, Lawrence H. \& Swartz, Michael D. 1992: Hebrew and Aramaic Incantation Texts from the Cairo Genizah: Selected Texts from Taylor-Schechter Box K1 (Semitic Texts and Studies 1). Sheffield: Sheffield Academic Press.

Segal, J.B. 2000: Catalogue of the Aramaic and Mandaic Incantation Bowls in the British Museum. London: British Museum Press.

Sims-Williams, Nicholas 1985: The Christian Sogdian Manuscript C2 (Berliner Turfantexte XII). Berlin: Akademie Verlag.

Sims-Williams, Nicholas 2012: Mitteliranische Handschriften: Teil 4. Iranian Manuscripts in Syriac Script in the Berlin Turfan Collection (Verzeichnis der Orientalischen Handschriften in Deutschland 18,4). Stuttgart: Franz Steiner.

Sims-Williams, Nicholas 2020: "The Sogdian 'Book of Life' Reconsidered". In: Artifact, Text, Context: Studies on Syriac Christianity in China and Central Asia (Orientalia-Patristica-Oecumenica, vol. 17). Ed. by Li Tang \& Dietmar W. Winkler. Wien: LIT Verlag: 113-119.

Smelova, Natalia 2015: "Manuscrits chrétiens de Qara Qoto: nouvelles perspectives de recherche". In: Le christanisme syriaque en Asie centrale et en Chine (Études syriaques, 12). Ed. by Pierre Marsone \& Pier Giorgio Borbone. Paris: Geuthner: 215-236.

SundERMANN, Werner 2004: “Turfan expeditions". In: Encyclopaedia Iranica, <https://www. iranicaonline.org/articles/turfan-expeditions-2>.

TocCI, Franco Michelini 1986: "Note e documenti di letteratura religiosa e parareligiosa giudaica". Annali dell'Istituto Universitario Orientale di Napoli. Nuova Serie, 46: 101108.

TondELLO, Marco 2018: "The Story of the Sleepers of Ephesus According to the Oldest Extant Text: Manuscript N.S.S. 4”. Journal of Eastern Christian Studies, 70 (1-2): 29-92.

UtAS, Bo 1968 [1969]: “The Jewish-Persian fragment from Dandan-Uiliq". Orientalia Suecana, 17: 123-136.

VAn Der Ploeg, J.P.M. 1983: The Christians of St. Thomas in South India and Their Syriac Manuscripts (Placid Lecture Series 3). Rome: Center for Indian and Inter-Religious Studies.

VAn EsbroecK, Michel 1994: "La Légende de Sept Dormants d'Éphèse selon de Codex Syriaque N.S. 4 de Saint-Pétersbourg”. Orientalia Christiana Analecta 247: 189-200. 
VAN Rompay, Lucas 1990: "Some Remarks on the Language of Syriac Incantation Texts". In: V Symposium Syriacum, 1988 (Orientalia Christiana Analecta 236). Ed. by René Lavenant. Rome: Pontificio Institutum Studiorum Orientalium: 369-381.

Voste, Jacques-Marie 1940: Liber Patrum (Fonti, ser. 2, fasc. 16: Caldei - diritto antico). Ed. by J.-M. Vosté. Vatican City: Typis polyglottis Vaticanis.

YAKuP, Abdurishid 2005: The Turfan Dialect of Uyghur (Turcologica 63). Wiesbaden: Harrassowitz.

YosHIDA, Jun'ichi \& CHIMEDDORJI, Jakhadai 2008: Harahoto shutsudo mongoru bunsho ken$k y \bar{u}$ [Study on the Mongolian documents found at Qaraqota], Tokyo. 